\title{
Development of Rapid, Sensitive, and Effective Plasmonic Nanosensor for the Detection of Vitamins in Infact Formula and Milk Samples
}

\author{
Duygu ÇIMEN and Adil DENIZLI* \\ Department of Chemistry, Hacettepe University, Ankara-06800, Turkey \\ ${ }^{*}$ Corresponding author: Adil DENIZLI $\quad$ E-mail: denizli@hacettepe.edu.tr
}

\begin{abstract}
The aim of the present study is to develop a surface plasmon resonance sensor for the detection of vitamin B2, vitamin B9, and vitamin B12 in food samples by using the molecular imprinting technique. The vitamin B2, vitamin B9, and vitamin B12 imprinted and the non-imprinted surface plasmon resonance sensor chip surfaces were characterized by using contact angle measurements, atomic force microscopy, ellipsometry, and Fourier transform infrared-attenuated total reflectance. The real-time detection of vitamin B2, vitamin B9, and vitamin B12 was analyzed by using aqueous solutions in the concentration range of $0.01 \mathrm{ng} / \mathrm{mL}-10 \mathrm{ng} / \mathrm{mL}$ for vitamin $\mathrm{B} 2$, $0.1 \mathrm{ng} / \mathrm{mL}-8.0 \mathrm{ng} / \mathrm{mL}$ for vitamin B9, and $0.01 \mathrm{ng} / \mathrm{mL}-1.5 \mathrm{ng} / \mathrm{mL}$ for vitamin B12. The limit of detection values was calculated as $1.6 \times 10^{-4} \mathrm{ng} / \mathrm{mL}$ for vitamin $\mathrm{B} 2,13.5 \times 10^{-4} \mathrm{ng} / \mathrm{mL}$ for vitamin $\mathrm{B} 9$, and $2.5 \times 10^{-4} \mathrm{ng} / \mathrm{mL}$ for vitamin B12, respectively. Selectivity experiments were performed by using vitamin B1 and vitamin B6. The reproducibility of surface plasmon resonance sensors was investigated both on the same day and on different days for four times. Validation studies of the prepared surface plasmon resonance (SPR) sensors were performed by liquid chromatography-tandem mass spectrometry (LC-MS/MS).
\end{abstract}

Keywords: Vitamin; molecular imprinting; surface plasmon resonance; food samples

Citation: Duygu ÇIMEN and Adil DENIZLI, "Development of Rapid, Sensitive, and Effective Plasmonic Nanosensor for the Detection of Vitamins in Infact Formula and Milk Samples," Photonic Sensors, 2020, 10(4): 316-332.

\section{Introduction}

Vitamins are organic compounds that are not produced by body cells. Therefore, vitamins need to be taken from nutrients and supplements daily. They play an important role in carbohydrate, fat and protein metabolism, healthy development of body, immunity against infections, and digestive functions [1-3]. Especially, vitamin B (such as vitamin $\mathrm{B} 2$, vitamin $\mathrm{B}$ 9, and vitamin B12) is very important for human health $[4,5]$. The demand of the body for vitamin B2 increases during the growth and pregnancy in children and women. The deficiency of vitamin B2 can be seen in the visual impairment, disorders of the nervous system, skin wounds, and various areas of the body such as inflammation of the skin. Vitamin B9 deficiency is often seen in elderly pregnant women, and premature infants. The use of vitamin B9 reduces the risk of disease related to the brain and spinal cord systems during pregnancy in women [6-9]. Genetic structure, division, and features of the cells are used for the development of the central nervous system of the baby in the early stages of pregnancy. 
Anemia and nervous system disorders are frequently seen in the lack of vitamin B12.

In recent years, the control of quality and freshness of foods is very important in the studies of food and biotechnology fields for both the development of the food industry and consumers [10]. Chemical and microbiological analyses are carried out in food industry for quality and safety purposes. The food quality can be determined by quantitative analyses such as color, aroma, vitamins, and amino acids. In addition, many factors, such as temperature, humidity, $\mathrm{pH}$, light, and oxygen, cause the loss of vitamins in foods during the production and storage processes. Food companies need advanced, precise, reliable, inexpensive, and fast analytical techniques to ensure the quality and safety of the products. One of the most important application methods in the food analysis is the sensor technology. The importance of sensor systems for the interaction and determination of biomolecules increases with the development of technology. Compared with classical analytical methods such as chemiluminescent enzyme immunoassay, and chromatography methods, sensor systems have advantages such as sensitivity, analysis time, and low cost [11-15]. Classical analytical methods are used for vitamin detection, however, it is a time-consuming and high-cost equipment, and requires skilled persons during the analysis. Therefore, rapid, selective, sensitive detection methods should be used for detection of vitamins.

Recently, surface plasmon resonance (SPR) based sensors are widely used in food analysis. SPR is a selective and sensitive sensor system that measures changes in the refractive index of electromagnetic waves generated by the reflection of polarized light on a metal surface [16-18]. In this study, we have combined the advantages of the SPR sensor systems and molecular imprinting technique.

Molecularly imprinted polymers (MIPs) are based on the polymerization of a cross-linker and a functional monomer around a target molecule and are used as recognition elements in sensor systems [19-24]. Sensors are rapid, selective, and sensitive devices for vitamin detection, and MIPs are integrated with sensor platforms in order to increase the sensitivity and selectivity of these platforms. Among the receptors, MIPs known as tailor-made receptors have many advantages such as cost-effective easy-prepared, robust, sensitive, and selective against the target molecules. Today, different types of sensors are fabricated for vitamin detection but the needs for better sensitive, selective, and reliable sensing platforms are a highly important area to analyze the food samples.

In this study, molecular imprinted based SPR sensors were developed for the detection of vitamin B2, vitamin B9, and vitamin B12 from infant formula and milk samples. The characterization studies of SPR chip surfaces were carried out by Fourier transform infrared-attenuated total reflectance (FTIR-ATR), contact angle, atomic force microscopy (AFM), and ellipsometry measurements. The selectivity studies of the SPR sensor were performed by using different $B$ vitamins such as vitamin B1 and vitamin B6. The reproducibility of SPR sensors was tested on the same day and on different days. Vitamin B2, B9, and B12 imprinted SPR sensors were employed for real-time detection of vitamin from food samples. Then, liquid chromatography-tandem mass spectrometry (LC-MS/MS) was used for validation studies.

\section{Materials and methods}

\subsection{Materials}

Vitamin B2, vitamin B9, vitamin B12, vitamin B1, vitamin B6, allyl mercaptan, ethylene glycol dimethacrylate (EGDMA), $\alpha, \alpha^{\prime}$-azoisobutyronitrile (AIBN), 2-hydroxyethyl methacrylate (HEMA), methacrylic acid (MAA), N-vinyl-2-pyrrolidone (VP), and clara-diastase were obtained from Sigma Chemical Co. (St. Louis, USA). Trypsin and all other chemicals were in analytical grade and 
purchased from Merck A.G. (Darmstadt, Germany).

\subsection{Preparation of SPR chip surfaces}

Firstly, to introduce allyl groups onto the SPR chip surface, the SPR chip was modified with allyl mercaptan $\left(\mathrm{CH}_{2} \mathrm{CHCH}_{2} \mathrm{SH}\right)$. In the first step, allyl mercaptan $(4 \mu \mathrm{L})$ was added onto the SPR chip surface. The preparation of vitamins B2, B9, and B12 imprinted SPR chips is shown in Fig. 1. In order to remove the unbound allyl mercaptan molecules, the SPR chip was washed with distilled water and ethanol, and then dried under the vacuum at $200 \mathrm{mmHg}, 25^{\circ} \mathrm{C}$.

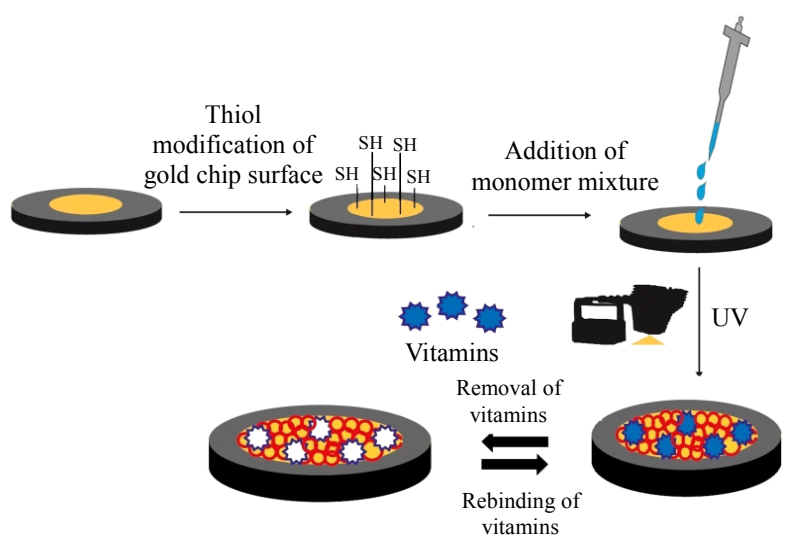

Fig. 1 Schematic representation of the preparation of vitamin imprinted chip surface.

The basic principle of molecular imprinting consists of prepolymerization complex formation between the template and functional monomers [20-22]. In this study, the selection of co-monomer for vitamins B2, B9, and B12 imprinted SPR sensors was studied with three different methacrylic acid (MAA), N-Vinyl-2-pyrrolidone (VP) and N-Methacryloyl-(L)-glutamic acid (MAGA) co-monomers. Firstly, monomer: vitamin pre-complex in molar ratio of 1:1 was prepared for each vitamin B2, B9, and B12 with three different MAA, VP, and MAGA co-monomers and synthesized vitamins B2, B9, and B12 imprinted polymeric films onto the SPR chip surface. The highest sensor signal for vitamins B2, B9, and B12 was observed in MAA, VP, and MAGA co-monomers, respectively (Fig. 2). The probable mechanism which governs the interactions is based on both hydrogen bonding and electrostatic interaction. Hydrogen bonding is dominant both between vitamin B2 and MAA co-monomer and between vitamin B12 and MAGA co-monomer, while electrostatic interactions are dominant for vitamin B9 and VP co-monomer because of their $p K_{a}$ values, which indicate their acidic strength $\left(p K_{a}\right.$ : 14.7 for VP monomer; $p K_{\mathrm{a} 1}: 3.5$ and $p K_{\mathrm{a} 2}: 4.3$ for vitamin B9).

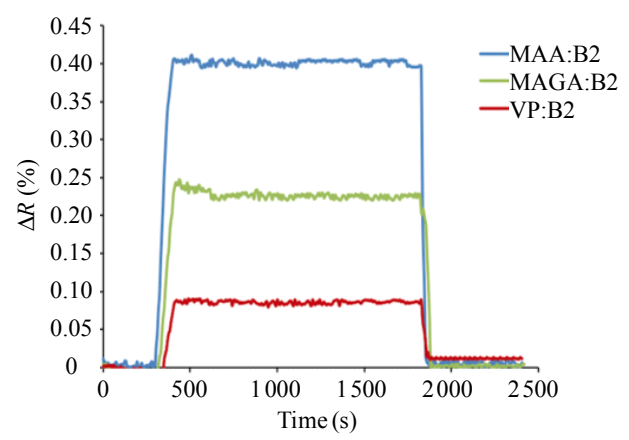

(a)

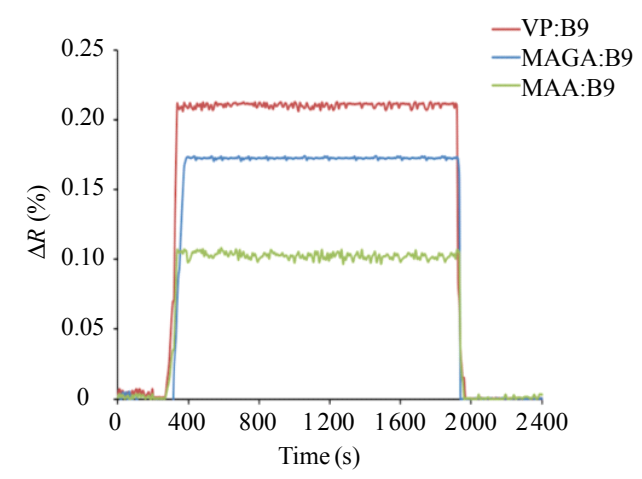

(b)

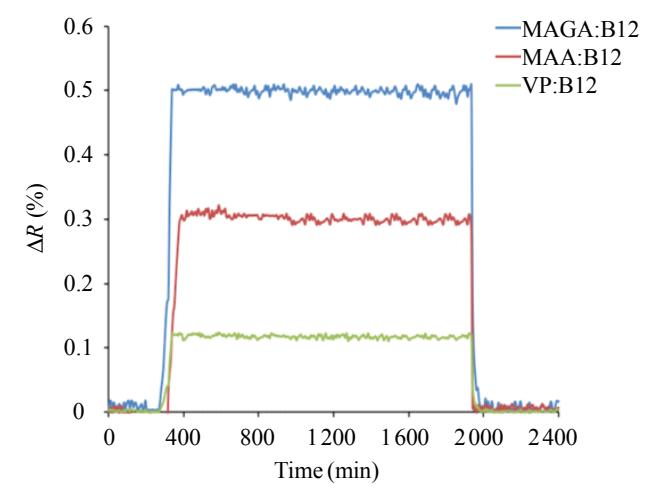

(c)

Fig. 2 Selection of monomer for (a) vitamins B2, (b) B9, and (c) B12 imprinted SPR sensors $\left(C_{\text {vitamin B2 }}: 0.01 \mathrm{ng} / \mathrm{mL}\right.$, $C_{\text {vitamin B9 }}: 1.0 \mathrm{ng} / \mathrm{mL}$, and $C_{\text {vitamin B12 }}: 0.1 \mathrm{ng} / \mathrm{mL}$ in all measurements). 
Vitamins in Infact Formula and Milk Samples

Methacrylic acid (MAA) as a model co-monomer was chosen for the preparation of the vitamin B2 imprinted SPR sensor. The pre-complex in different molar ratios $(1: 1 ; 5: 1 ; 10: 1$, and 20:1) was prepared at room temperature for $2 \mathrm{~h}$ with vitamin $\mathrm{B} 2$ and methacrylic acid (MAA) co-monomer. Vitamin B2 imprinted and non-imprinted polymeric films were synthesized onto the SPR chip surface. The maximum imprinting factor $(I F)$ values were observed at MAA:vitamin B2 (10:1) due to the stoichiometric ratio. In all experiments, the studies were performed at these molar ratios. For the preparation of vitamin B2 imprinted [P(HEMA-MAA)] polymeric film onto the SPR chip surface, HEMA $(6.1 \mu \mathrm{L})$, EGDMA $(18.8 \mu \mathrm{L})$, and MAA:vitamin B2 pre-complex in molar ratio of 10:1 $(210 \mu \mathrm{L})$ were mixed in a rotator at $200 \mathrm{rpm}$ for $30 \mathrm{~min}$. Then, the initiator AIBN (4 mg) was added into this stock solution. After the preparation of these solutions, $3 \mu \mathrm{L}$ solution was dropped onto the modified SPR chip surface. Then, ultraviolet (UV) light was applied for the UV-polymerization for $20 \mathrm{~min}$ $(100 \mathrm{~W}, 365 \mathrm{~nm})$.

VP as a model monomer was chosen for the preparation of vitamin B9 imprinted SPR sensor. The pre-complex in different molar ratios $(1: 1,2: 1$, $4: 1$, and 8:1) was prepared at room temperature for $2 \mathrm{~h}$ with vitamin B9 and VP co-monomer. Vitamin B9 imprinted and non-imprinted polymeric films were synthesized onto the SPR chip surface. The maximum $I F$ values were observed at VP:vitamin B9 $(4: 1)$ due to the stoichiometric ratio. In all experiments, the studies were performed at these molar ratios. For the preparation of vitamin B9 imprinted [P(HEMA-VP)] polymeric film onto the SPR chip surface, HEMA $(6.1 \mu \mathrm{L})$, EGDMA $(18.8 \mu \mathrm{L})$, and VP:vitamin B9 pre-complex in molar ratio of $4: 1(210 \mu \mathrm{L})$ were mixed for $30 \mathrm{~min}$ in a rotator with $200 \mathrm{rpm}$. Then, the initiator AIBN $(4 \mathrm{mg})$ was added into this stock solution. After the preparation of these solutions, $3 \mu \mathrm{L}$ solution was dropped onto the modified SPR chip surface. Then, UV light was applied for the UV-polymerization for $20 \mathrm{~min}(100 \mathrm{~W}, 365 \mathrm{~nm})$.

MAGA as a model co-monomer was chosen for the preparation of the vitamin B12 imprinted SPR sensor. The pre-complex in different molar ratios $(1: 1,2: 1,5: 1$, and 10:1) was prepared at room temperature for $2 \mathrm{~h}$ with vitamin B12 and MAGA co-monomer. Vitamin B12 imprinted and non-imprinted polymeric films were synthesized onto the SPR chip surface. The maximum $I F$ values were observed at MAGA:vitamin B12 (5:1) due to the stoichiometric ratio. In all experiments, the studies were performed at these molar ratios. For the preparation of vitamin $\mathrm{B} 12$ imprinted [P(HEMA-MAGA)] polymeric film onto the SPR chip surface, HEMA $(6.1 \mu \mathrm{L})$, EGDMA $(18.8 \mu \mathrm{L})$, and MAGA:vitamin B12 pre-complex in the ratio of $5: 1(210 \mu \mathrm{L})$ were mixed for $30 \mathrm{~min}$ in a rotator with $200 \mathrm{rpm}$. Then, the initiator AIBN ( $4 \mathrm{mg}$ ) was added into this stock solution. After the preparation of these solutions, $3 \mu \mathrm{L}$ solution was dropped onto the modified SPR chip surface. Then, UV light was applied for the UV-polymerization for $20 \mathrm{~min}$ $(100 \mathrm{~W}, 365 \mathrm{~nm})$. Also, the non-imprinted SPR chip was prepared with the same procedure without vitamin. For the removal of vitamins from the polymeric film, the SPR chip was washed with $0.5 \mathrm{M} \mathrm{NaCl}$ solution.

\subsection{Characterization of vitamins B2, B9, and B12 imprinted SPR chip surfaces}

The characterization of vitamin imprinted and non-imprinted SPR chips were performed by using ellipsometry, atomic force microscope (AFM), Fourier transform infrared-attenuated total reflectance (FTIR-ATR), and contact angle. The thicknesses of the polymeric films on the SPR chip surfaces were determined by using nanofilm EP3-nulling ellipsometry (Gottingen, Germany). The measurement of the contact angle was realized with the sessile drop on the SPR chip 
surfaces (Hamburg, Germany, KRUSS DSA100). The surface morphology of SPR chips, AFM analysis (Oxford, UK, Nanomagnetics Instruments) was applied in the tapping mode. FTIRATR (8000 Series, Shimadzu, Tokyo, Japan) was used for the estimation of characteristic functional groups of SPR chip surfaces.

\subsection{Kinetic analyses}

Kinetic analyses of vitamins B2, B9, and B12 imprinted SPR sensors were performed by using an SPR Imager II (GWC Technologies, Madison, ABD). The detection of vitamins B2, B9, and B12 from the aqueous solution was performed by using vitamin B2, B9, and B12 imprinted and non-imprinted SPR sensors. Firstly, vitamins B2, B9, and B12 imprinted SPR sensors were equilibrated with $0.1 \mathrm{M}$ phosphate buffer ( $\mathrm{pH}$ 7.4). Then, the solutions at different vitamin concentrations [vitamin B2 $(0.01 \mathrm{ng} / \mathrm{mL}-$ $10.0 \mathrm{ng} / \mathrm{mL})$, vitamin B9 $(0.1 \mathrm{ng} / \mathrm{mL}-8.0 \mathrm{ng} / \mathrm{mL})$, and vitamin B12 $(0.01 \mathrm{ng} / \mathrm{mL}-1.5 \mathrm{ng} / \mathrm{mL})]$ were applied to SPR sensors. In order to remove vitamins B2, B9, and B12 from the polymeric film on chips, SPR chips were incubated with $0.5 \mathrm{M} \mathrm{NaCl}$ solution. The linear relationship between vitamin increased concentrations and percent resonance frequency change $[\Delta R(\%)]$ of vitamins $\mathrm{B} 2, \mathrm{~B} 9$, and $\mathrm{B} 12$ imprinted SPR sensors was analyzed by the SPR system (GenOptics, SPRi-Lab, Orsay, France).

Vitamin $\mathrm{B} 1\left(\mathrm{C}_{12} \mathrm{H}_{17} \mathrm{~N}_{4} \mathrm{SO}, \mathrm{MW}: 337.27 \mathrm{~g} / \mathrm{mol}\right)$ and vitamin $\mathrm{B} 6\left(\mathrm{C}_{8} \mathrm{H}_{11} \mathrm{NO}_{3}, \mathrm{MW}: 169.18 \mathrm{~g} / \mathrm{mol}\right)$ were applied as competitive vitamins for selectivity studies of the vitamin B2 imprinted SPR sensor. Vitamin B2, vitamin B1, and vitamin B6, which were similar in terms of structure and molecular weight, were used in the competitive binding studies. The solution of all competitive vitamins with a concentration of $0.01 \mathrm{ng} / \mathrm{mL}(\mathrm{pH} 7.4$ ) was applied to SPR sensors for selectivity studies of the vitamin B2. The obtained $\Delta R$ values were used for the calculation of selectivity coefficients.

Vitamin B12 $\left(\mathrm{C}_{63} \mathrm{H}_{88} \mathrm{CoN}_{14} \mathrm{O}_{14} \mathrm{P}\right.$, MW: $1355.66 \mathrm{~g} / \mathrm{mol}$ and vitamin $\mathrm{B} 1\left(\mathrm{C}_{12} \mathrm{H}_{17} \mathrm{~N}_{4} \mathrm{SO}\right.$, MW: $\left.337.27 \mathrm{~g} / \mathrm{mol}\right)$ were applied as competitive vitamins for selectivity studies of the vitamin B9 imprinted SPR sensors. Vitamin B9, vitamin B12, and vitamin B1, which are similar in terms of structure and molecular weight, were used in the competitive selective studies. The solution of all competitive vitamins with a concentration of $1.0 \mathrm{ng} / \mathrm{mL}$ (pH 7.4) was applied to SPR sensors for selectivity studies of the vitamin B9. The obtained $\Delta R$ values were used for the calculation of selectivity coefficients.

Vitamin B9 $\left(\mathrm{C}_{19} \mathrm{H}_{19} \mathrm{~N}_{7} \mathrm{O}_{6}, \mathrm{MW}: 441.40 \mathrm{~g} / \mathrm{mol}\right)$ and vitamin $\mathrm{B} 1\left(\mathrm{C}_{12} \mathrm{H}_{17} \mathrm{~N}_{4} \mathrm{SO}\right.$, MW: $\left.337.27 \mathrm{~g} / \mathrm{mol}\right)$ were applied as competitive vitamins for selectivity studies of the vitamin B12 imprinted SPR sensors. Vitamin B12, vitamin B9, and vitamin B1, which are similar in terms of structure and molecular weight, were used in the competitive binding studies.

The solution of all competitive vitamins with a concentration of $0.1 \mathrm{ng} / \mathrm{mL}$ ( $\mathrm{pH} 7.4$ ) was applied to SPR sensors for selectivity studies of the vitamin B12. The obtained $\Delta R$ values were used for the calculation of selectivity coefficients.

The reproducibility of vitamin imprinted SPR sensors was realized by equilibration-bindingregeneration cycles for several times. The reproducibility of the SPR sensors was tested on the same day and on different days. The obtained $\Delta R$ values were used for the calculation of the reproducibility and storage stability. Vitamin B2 $(0.01 \mathrm{ng} / \mathrm{mL})$, vitamin B9 $(0.5 \mathrm{ng} / \mathrm{mL})$, and vitamin B12 $(0.1 \mathrm{ng} / \mathrm{mL})$ solutions were applied to SPR sensors for the reproducibility and storage stability analysis.

\subsection{Extraction and determination of vitamins in infant formula and milk samples}

The infant formula and milk samples were used to investigate the real-time and high selectivity applicability of vitamins B2, B9, and B12 imprinted SPR sensors. In order to detect vitamins B2, B9, and B12 from food samples with SPR sensors, vitamins 
B2, B12, and B9 extracts were obtained from infant formula and milk samples. Extraction methods of each types of vitamins B2, B9, and B12 in infant formula and milk samples are given below.

In order to obtain vitamin B2 from the infant formula and milk samples, the food samples were separated by the oil layer by centrifugation at $2000 \mathrm{rpm}$ at $10{ }^{\circ} \mathrm{C}$ for $10 \mathrm{~min}$. It was taken from $5.0 \mathrm{~mL}$ food extract samples and diluted with deionized water. $15 \mathrm{mg}$ of trypsin and $15 \mathrm{mg}$ of clara-diastase were added to degrade the high molecular weight compounds and then hydrolyzed in a shaking hot water bath $\left(40{ }^{\circ} \mathrm{C}\right)$ for $30 \mathrm{~min}$. The vitamin B2 extracts solutions were centrifuged at $8000 \mathrm{rpm}$ for $10 \mathrm{~min} .5 .0 \mathrm{~mL}$ of the supernatant was used by passing through solid phase extraction (SPE) cartridge in food analysis [25].

In the preparation of vitamin B9 extracts, infant formula and milk samples were taken in a tube, which were added with $10 \mathrm{~mL}$ of $0.1 \mathrm{M}$ dibasic potassium phosphate solution ( $\mathrm{pH}$ 6.0). The test tube was kept in a shaking hot water bath at $100{ }^{\circ} \mathrm{C}$ for $30 \mathrm{~min}$ and cooled at room temperature. The food samples were centrifuged at $3000 \mathrm{rpm}$ for $20 \mathrm{~min}$ and the lipid layer was removed from the food samples. The food samples were added with $70 \mu \mathrm{L}$ of formic

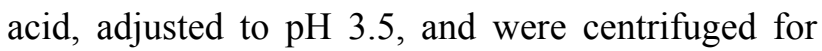
$20 \mathrm{~min}$ at $3000 \mathrm{rpm}$ to precipitate vitamin and proteins. Then, food extracts were added with $6.0 \mathrm{~mL}$ of methanol, $6.0 \mathrm{~mL}$ of water, and $0.03 \mathrm{mM}$ dibasic potassium phosphate. $5.0 \mathrm{~mL}$ of the supernatant was used by passing through the SPE cartridge in food analysis [26].

For the determination of vitamin B12 from infant formula and milk samples, $25 \mathrm{~mL}$ of the food samples was taken and diluted to a $250 \mathrm{~mL}$ flask by adding deionized water. $1.0 \mathrm{~mL}$ of food solutions was added with $6.0 \mathrm{~L}$ of $50 \mathrm{mM}$ sodium acetate buffer ( $\mathrm{pH} 4.0$ ), $1.0 \mathrm{~mL}$ of $1.0 \%$ sodium cyanide, and $0.25 \mathrm{~g}$ of $\beta$-amylase. The vitamin B12 solutions were incubated at $37^{\circ} \mathrm{C}$ for $3 \mathrm{~h}$. After cooling to room temperature, each food solution was transferred to a $100 \mathrm{~mL}$ flask and completed with deionized water. $5.0 \mathrm{~mL}$ of the supernatant was used by passing through the SPE cartridge in food analysis [27].

The food samples were prepared under low light and in the ice. For infant formula and milk sample studies, vitamins $\mathrm{B} 2, \mathrm{~B} 9$, and $\mathrm{B} 12$ solution in the $1.0 \mathrm{ng} / \mathrm{mL}$ concentration was spiked in obtained infact formula and milk extract. Vitamins B2, B9, and B12 ingredients in spiked infact formula and milk samples were determined by using both prepared SPR sensors and LC-MS/MS.

\section{Results and discussion}

\subsection{Characterization of vitamins B2, B9, and B12 imprinted SPR chips}

The surface properties of vitamin imprinted polymeric films were determined by ellipsometry, AFM, contact angle, and FTIR-ATR.

The FTIR-ATR spectra of vitamins B2, B9, and B12 imprinted polymeric films were shown in Fig. 3. The characteristic bands of riboflavin-5 phosphate $\left(\mathrm{PO}_{3}{ }^{-2}\right)$ have asymmetric bands at $1051 \mathrm{~cm}^{-1}$. In the FTIR-ATR spectrum of poly(hydroxyethyl methacrylate-methacrylic acid [P(HEMA-MAA)] polymeric film, $-\mathrm{OH}$ stretching band at $3319 \mathrm{~cm}^{-1}$, aliphatic $\mathrm{C}-\mathrm{H}$ stretching band at $2950 \mathrm{~cm}^{-1}$, carbonyl band at $1730 \mathrm{~cm}^{-1}$, and amide bands at $1643 \mathrm{~cm}^{-1}$ and $1529 \mathrm{~cm}^{-1}$ were observed. As seen from the FTIR-ATR spectra, vitamin B2 and MAA functional monomers were introduced into the polymeric film structure [Fig. 3(a)] [28, 29].

The characteristic bands of folic acid structure have pterin ring $(\mathrm{N}-\mathrm{H})$ bands and glutamic acid $(-\mathrm{OH})$ stretching bands at $3600 \mathrm{~cm}^{-1}-$ $3400 \mathrm{~cm}^{-1}, \mathrm{~N}-\mathrm{H}$ stretching band at $1607 \mathrm{~cm}^{-1}$, and $\mathrm{C}=\mathrm{O}$ stretching band at $1696 \mathrm{~cm}^{-1}$. The bands at $1511 \mathrm{~cm}^{-1}-1482 \mathrm{~cm}^{-1}$ are characteristic phenyl and the absorption bands of the pterin ring. The FTIR-ATR spectra of vitamin B9 and VP functional monomers were introduced into the polymeric film 
structure [Fig. 3(b)] [30, 31].

As seen in Fig. 3(c), the characteristic bands in vitamin B12 structure and MAGA monomer have $\mathrm{N}-\mathrm{H}$ bands (amide II) at $3329 \mathrm{~cm}^{-1}$, the aliphatic $\mathrm{C}-\mathrm{H}$ stretching band at $2913 \mathrm{~cm}^{-1}$ and $2849 \mathrm{~cm}^{-1}$, carbonyl band at $1761 \mathrm{~cm}^{-1},-\mathrm{CH}_{2}$ stretching band at
$1435 \mathrm{~cm}^{-1}$, asymmetric $\mathrm{C}-\mathrm{O}-\mathrm{C}$ stretching band at $1305 \mathrm{~cm}^{-1}$, and $\mathrm{C}-\mathrm{H}$ stretching band of $1150 \mathrm{~cm}^{-1}$. As seen from the FTIR-ATR spectra, vitamin B12 and MAGA functional monomers were introduced into the polymeric film structure [Fig. 3(c)] [32, 33].

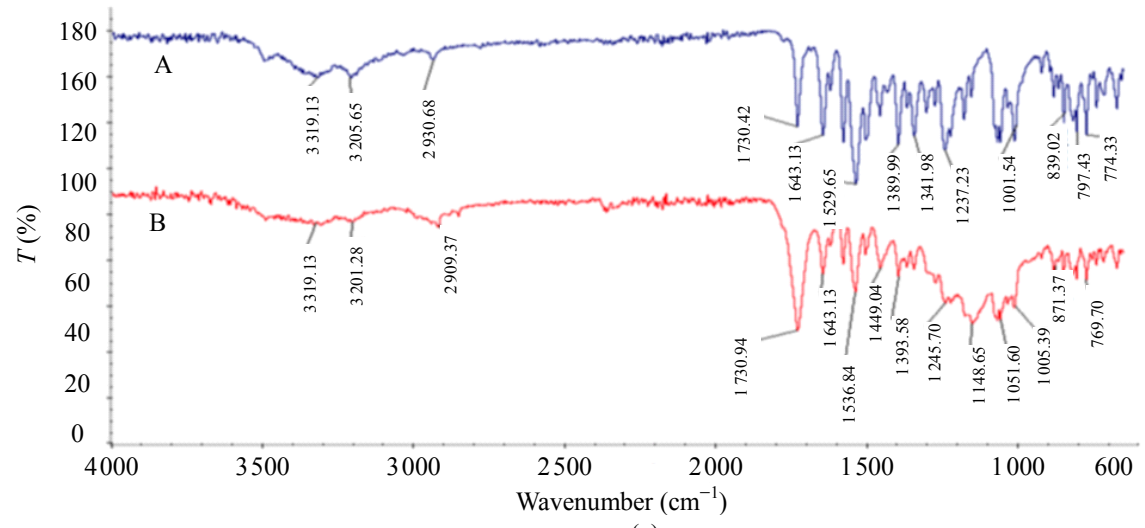

(a)

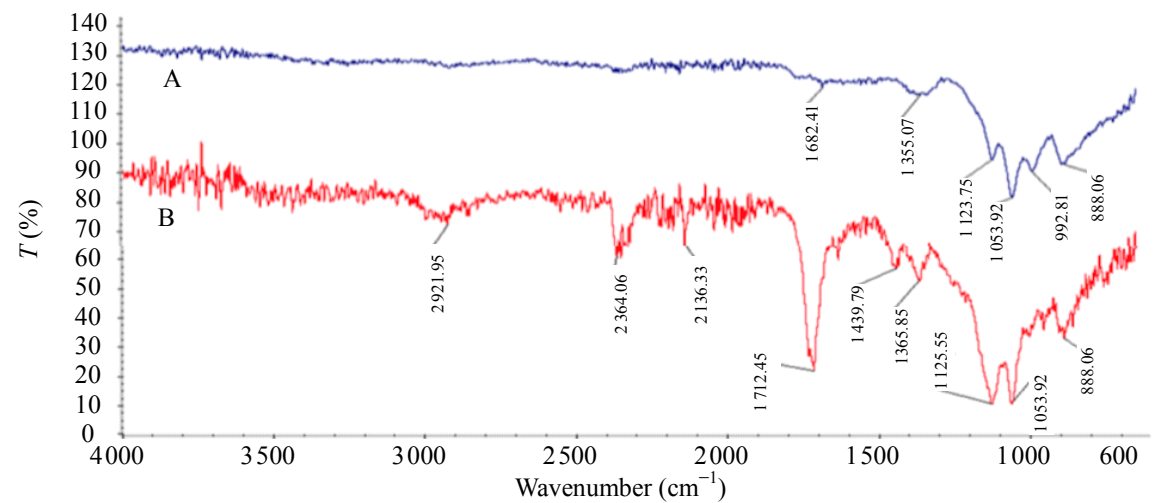

(b)

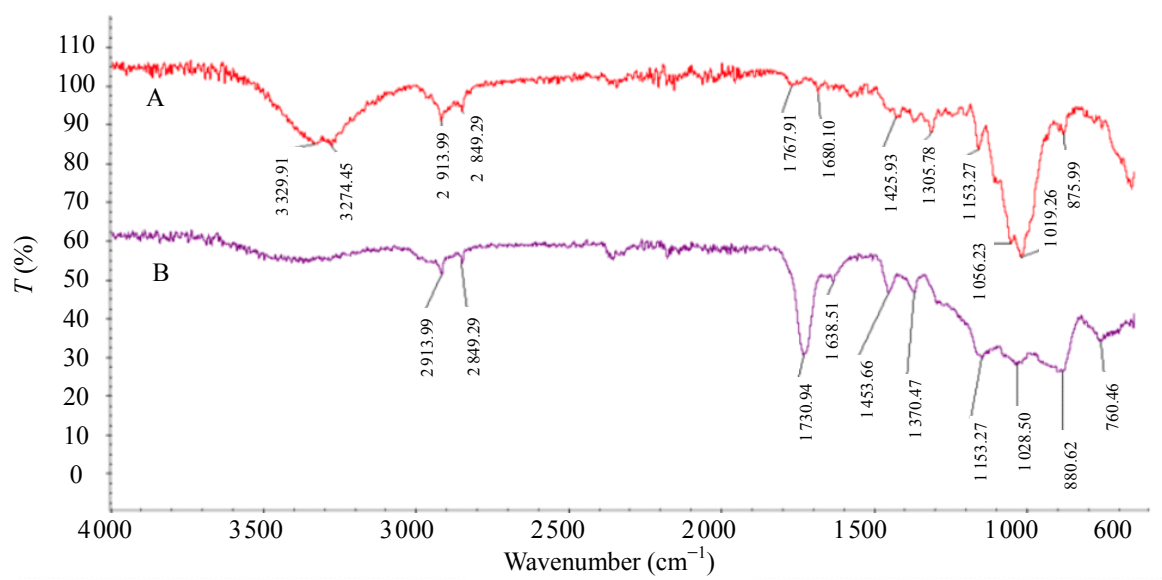

(c)

Fig. 3 FTIR-ATR spectra of (a) vitamins B2, (b) B9, and (c) B12 imprinted (A) and non-imprinted (B) films onto the chip surface.

The bare gold surface and vitamins B2, B9, and B12 imprinted SPR chips were characterized by contact angle measurements. The water contact angle (WCA) value of bare gold surface and 
Vitamins in Infact Formula and Milk Samples

vitamins B2, B9, and B12, imprinted SPR sensor surfaces were found to be $82.2^{\circ} \pm 0.65^{\circ}, 63.4^{\circ} \pm 0.9^{\circ}$, $68.7^{\circ} \pm 0.5^{\circ}$, and $58.6^{\circ} \pm 0.34^{\circ}$, respectively (Fig. 4). A decrease in the contact angle value of the bare gold surface and vitamins B2, B9, and B12 imprinted SPR sensor surfaces showed that the molecular imprinting could be achieved successfully onto the modified SPR sensor surface. Surface morphologies of the bare gold chip surface and vitamins B2, B9, and B12 imprinted SPR sensors were characterized with AFM and ellipsometric measurements. With AFM measurements, the surface deepening of the bare gold chip surface and vitamins B2, B9, and B12 imprinted SPR sensors were determined as $6.09 \mathrm{~nm}, 65.0 \mathrm{~nm}, 60.65 \mathrm{~nm}$, and $36.36 \mathrm{~nm}$, respectively. AFM images showed that a uniform polymeric film was synthesized onto the SPR sensor surface. The thickness values of vitamins B2, B9, and B12 imprinted polymeric film onto the SPR sensor surface were also determined with ellipsometry measurements as $62.65 \mathrm{~nm}$, $67.7 \mathrm{~nm}, 70.67 \mathrm{~nm}$, and $69.2 \mathrm{~nm}$, respectively (Fig. 4).

Bare gold surfaces

(a)
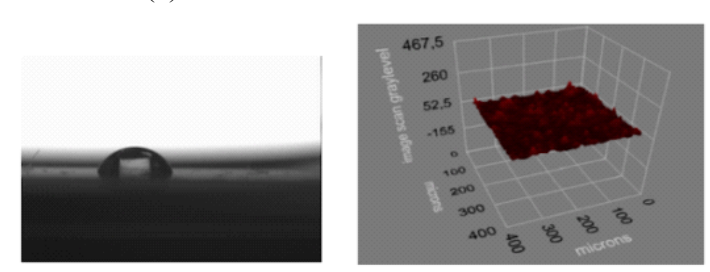

Vitamin B2 imprinted SPR sensor surfaces
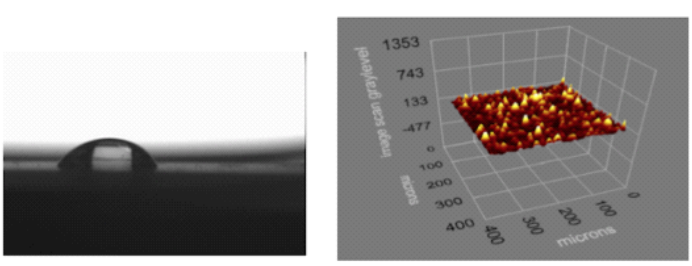

Vitamin B9 imprinted SPR sensor surfaces
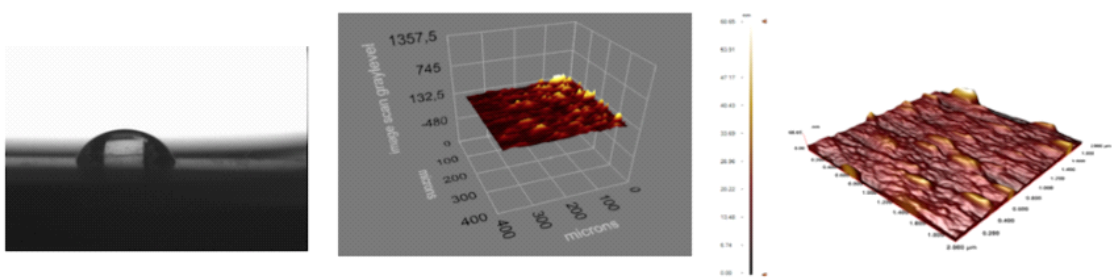

Vitamin B12 imprinted SPR sensor surfaces
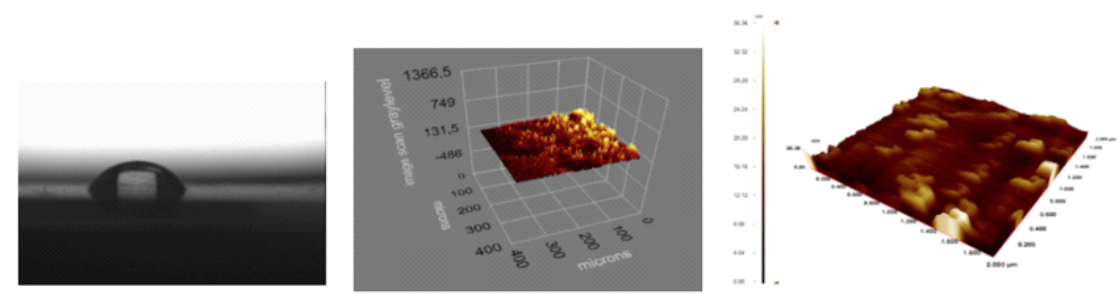

Fig. 4 Characterization of bare gold surface and vitamins B2, B9, and B12 imprinted SPR sensor surfaces [(a) contact angles, (b) ellipsometry images, and (c) AFM studies]. 


\subsection{Real-time vitamins B2, B9, and B12 detection studies with SPR sensors}

The retention behavior of the molecular imprinted polymer is compared with the non-imprinted polymer (NIP) to evaluate the $I F$. IF was calculated as $\Delta R(\%)$ between the imprinted and non-imprinted polymeric films [34] using (1):

$$
I F=\Delta R_{(\mathrm{MIP})} / \Delta R_{(\mathrm{NIP})} .
$$

The obtained $\Delta R$ values of the vitamins $\mathrm{B} 2, \mathrm{~B} 9$, and B12 imprinted polymeric films were higher than those of the non-imprinted polymeric films (Fig. 5). These results clearly indicate the presence of vitamins $\mathrm{B} 2$, B9, and B12 specific binding sites (i.e., molecular cavities). The maximum $I F$ values were observed at MAA:vitamin B2 (10:1), VP:vitamin B9 (4:1), and MAGA:vitamin B12 (5:1) due to the stoichiometric ratio. In all experiments, the studies were performed at these molar ratios.

Vitamins B2, B9, and B12 imprinted SPR sensors were equilibrated with $0.1 \mathrm{M}$ phosphate buffer ( $\mathrm{pH}$ 7.4). After the equilibration step, vitamin solutions at different vitamin concentrations [vitamin B2 $(0.01 \mathrm{ng} / \mathrm{mL}-10.0 \mathrm{ng} / \mathrm{mL})$, vitamin B9 $(0.1 \mathrm{ng} / \mathrm{mL}-8.0 \mathrm{ng} / \mathrm{mL})$, and vitamin B12 $(0.01 \mathrm{ng} / \mathrm{mL}-1.5 \mathrm{ng} / \mathrm{mL})]$ were applied to the SPR sensors $\left(10 \mathrm{~mL}, 1.5 \mathrm{~mL} / \mathrm{min}, 25^{\circ} \mathrm{C}\right)$. As seen in Fig. 6, an increase in the vitamins B2, B9, and B12 concentrations caused an enormous increase in the SPR sensor response. For the removal of vitamins, the SPR chip surfaces were washed with $0.5 \mathrm{M} \mathrm{NaCl}$ solution. The SPR sensor response increased linearly, and then saturation started at a plateau value of a relatively high vitamins $\mathrm{B} 2, \mathrm{~B} 9$, and $\mathrm{B} 12$ concentrations because of the saturation of accessible imprinted molecular cavities onto the SPR sensor surface. All kinetic analyzes were completed in $40 \mathrm{~min}$.

The kinetic analysis of vitamins B2, B9, and B12 was performed with vitamin imprinted and nonimprinted SPR sensors in aqueous solutions in real

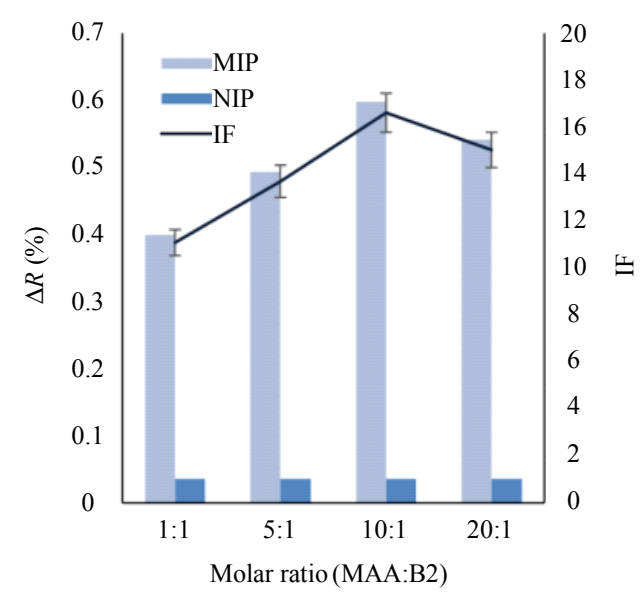

(a)

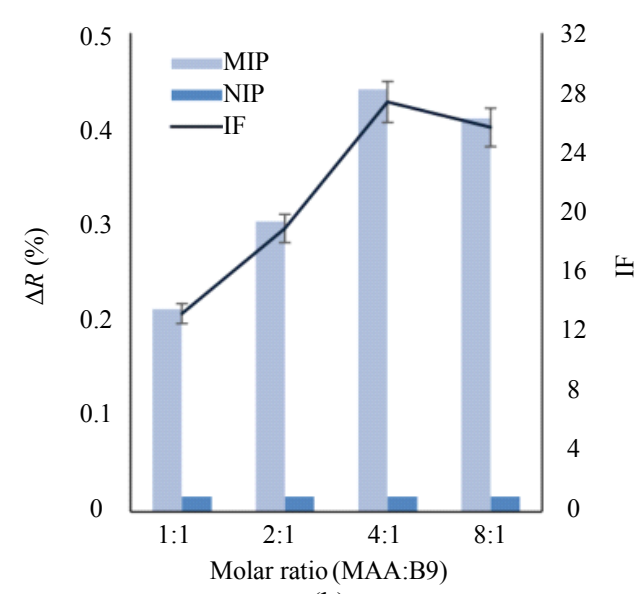

(b)

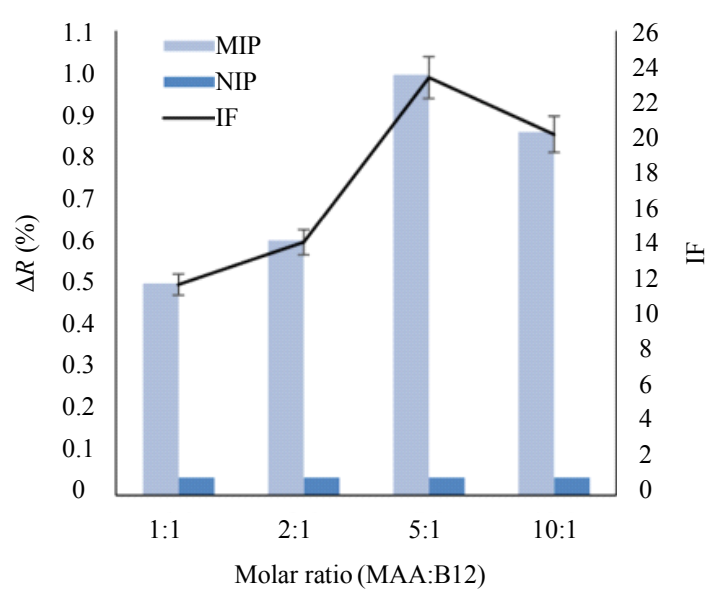

(c)

Fig. 5 Imprinting factors of vitamins (a) B2, (b) B9, and (c) B12 imprinted and non-imprinted polymers $\left(C_{\text {vitamin } \mathrm{B} 2}\right.$ : $0.01 \mathrm{ng} / \mathrm{mL}, C_{\text {vitamin B9}}: 1.0 \mathrm{ng} / \mathrm{mL}$, and $C_{\text {vitamin B12 }}: 0.1 \mathrm{ng} / \mathrm{mL}$ in all measurements).

time. Langmuir, Freundlich, and LangmuirFreundlich adsorption models using kinetic data were applied to describe the binding behavior and 
the possible interactions between vitamins B2, B9, and B12 molecules and their imprinted SPR sensors. The isotherm models (Scatchard, Langmuir, Freundlich, and Langmuir-Freundlich isotherms) can be determined by using (2), (3), (4), and (5), respectively.

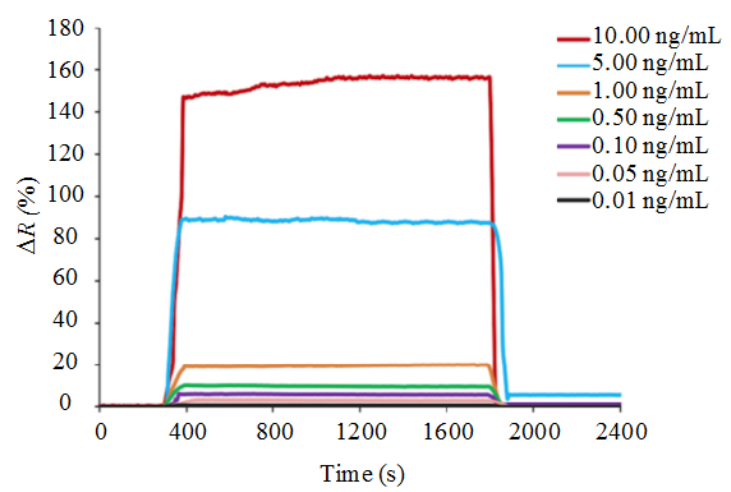

(a)

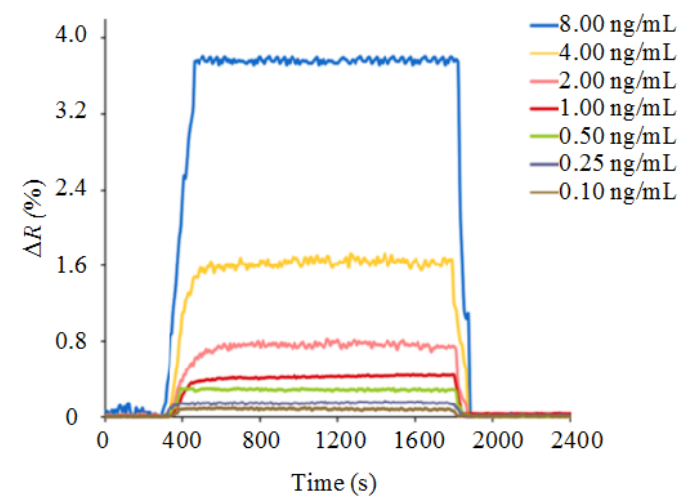

(b)

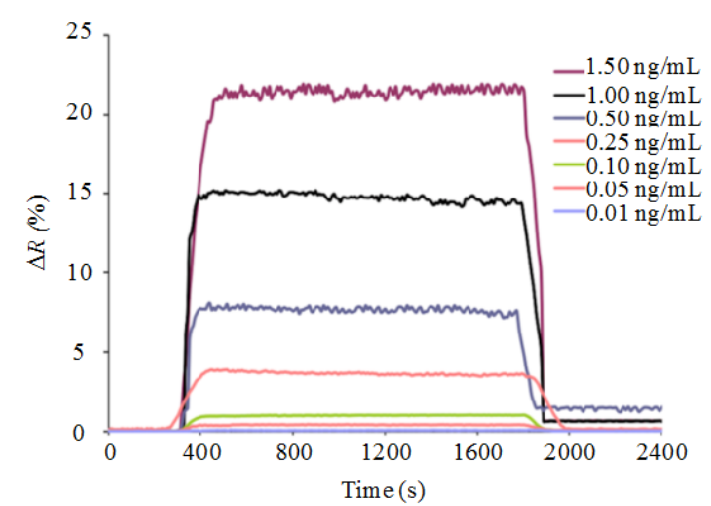

(c)

Fig. 6 Effects of the concentration [(a) vitamin B2 imprinted SPR sensor, (b) vitamin B9 imprinted SPR sensor, and (c) vitamin B12 imprinted SPR sensor].
Scatchard
$\Delta R_{\mathrm{ex}} / C=K_{A}\left(\Delta R_{\max }-\Delta R_{\mathrm{eq}}\right)$
Langmuir
$\Delta R=\Delta R_{\max } C / K_{D}+C$

Freundlich $\quad \Delta R=\Delta R_{\max } C^{1 / n}$

Langmuir-Freundlich $\Delta R=\Delta R_{\max } C^{1 / n} / K_{D}+C^{1 / n}$

The responses measured by binding and concentration of vitamins $\mathrm{B} 2, \mathrm{~B} 9$, and $\mathrm{B} 12$ are $\Delta R$ and $C(\mathrm{ng} / \mathrm{mL})$, respectively. The heterogeneity index of the Freundlich isotherm is $1 / n . K_{D}(\mathrm{~mL} / \mathrm{ng})$ and $K_{A}(\mathrm{ng} / \mathrm{mL})$ are also the forward and reverse equilibrium constants; subscripts ex, max, and eq indicate experimental, maximum, and equilibrium, respectively [20,35].

Langmuir adsorption isotherm model is based on the acceptance of homogeneously distribution of equal energy, whereas Freundlich adsorption isotherm model demonstrates heterogeneous interactions. The heterogeneity index of the Freundlich isotherm $(1 / n)$ is between 0 and 1 . Langmuir, Freundlich, and Freundlich-Langmuir adsorption parameters were given in Table 1. According to the obtained data, these results were in good agreement with the Langmuir model $\left(R^{2}=\right.$ 0.998 for vitamin $\mathrm{B} 2 ; R^{2}=0.987$ for vitamin $\mathrm{B} 9$; $R^{2}=0.999$ for vitamin $\mathrm{B} 12$ ), which means that the binding sites of vitamins B2, B9, and B12 molecules onto the vitamins B2, B9, and B12 imprinted SPR chip surfaces are on a homogeneously distributed monolayer, co-energy, and minimal lateral interaction.

Figure 7 shows the linear range of $0.01 \mathrm{ng} / \mathrm{mL}-$ $10 \mathrm{ng} / \mathrm{mL}$ for vitamin B2, $0.1 \mathrm{ng} / \mathrm{mL}-8.0 \mathrm{ng} / \mathrm{mL}$ for vitamin $\mathrm{B} 9$, and $0.01 \mathrm{ng} / \mathrm{mL}-1.5 \mathrm{ng} / \mathrm{mL}$ for vitamin B12. The data obtained from the concentration range were used to determine the limit of detection $(L O D)$ and limit of quantitation $(L O Q)$ values of the vitamins B2, B9, and B12 imprinted SPR sensors. $S$ is the standard deviation of the intercept and $m$ is the slope of the regression line [36-38].

$$
\begin{aligned}
& L O D=3.3 \mathrm{~S} / \mathrm{m} \\
& L O Q=10 \mathrm{~S} / \mathrm{m} .
\end{aligned}
$$


Table 1 Kinetic and isotherm parameters [(a) vitamin B2, (b) vitamin B9, and (c) vitamin B12 imprinted SPR sensors].

(a)

\begin{tabular}{|c|c|c|c|c|}
\hline $\begin{array}{l}\text { Equilibrium } \\
\text { analysis } \\
\text { (Scathard) }\end{array}$ & $\begin{array}{l}\text { Association } \\
\text { kinetics } \\
\text { analysis }\end{array}$ & Langmuir & Freundlich & $\begin{array}{l}\text { Langmuir- } \\
\text { Freundlich }\end{array}$ \\
\hline$\Delta R_{\max }: 4.579$ & $\begin{array}{c}k_{a}(\mathrm{ng} / \mathrm{mL} . \mathrm{s}): \\
0.003\end{array}$ & $\begin{array}{c}\Delta R_{\max }: \\
56.82\end{array}$ & $\begin{array}{l}\Delta R_{\max }: \\
20.477\end{array}$ & $\Delta R_{\max }: 2.708$ \\
\hline $\begin{array}{c}K_{A},(\mathrm{ng} / \mathrm{mL}): \\
5.609\end{array}$ & $k_{d}(1 / \mathrm{s}): 0.003$ & $K_{D}: 0.988$ & $1 / n: 0.7031$ & $1 / n: 0.7031$ \\
\hline $\begin{array}{c}K_{D},(\mathrm{~mL} / \mathrm{ng}): \\
0.178\end{array}$ & $\begin{array}{c}K_{A}(\mathrm{ng} / \mathrm{mL}): \\
0.929\end{array}$ & $K_{A}: 1.067$ & $R^{2}: 0.959$ & $K_{D}: 1.069$ \\
\hline \multirow[t]{2}{*}{$R^{2}: 0.789$} & $\begin{array}{c}K_{D}(\mathrm{~mL} / \mathrm{ng}): \\
1.077\end{array}$ & $R^{2}: 0.998$ & & $K_{A}: 0.935$ \\
\hline & $R^{2}: 0.955$ & & & $R^{2}: 0.833$ \\
\hline
\end{tabular}

(b)

\begin{tabular}{|c|c|c|c|c|}
\hline $\begin{array}{l}\text { Equilibrium } \\
\text { analysis } \\
\text { (Scathard) }\end{array}$ & $\begin{array}{c}\text { Association } \\
\text { kinetics analysis }\end{array}$ & Langmuir & Freundlich & $\begin{array}{l}\text { Langmuir- } \\
\text { Freundlich }\end{array}$ \\
\hline$\Delta R_{\max }: 3.463$ & $\begin{array}{c}k_{a}(\mathrm{ng} / \mathrm{mL} \cdot \mathrm{s}): \\
0.0004\end{array}$ & $\begin{array}{c}\Delta R_{\max }: \\
1.398\end{array}$ & $\begin{array}{l}\Delta R_{\max }: \\
2.170\end{array}$ & $\Delta R_{\max }: 0.302$ \\
\hline $\begin{array}{c}K_{A},(\mathrm{ng} / \mathrm{mL}): \\
0.171\end{array}$ & $k_{d}(1 / \mathrm{s}): 0.001$ & $K_{D}: 1.696$ & $1 / n: 0.8139$ & $1 / n: 0.8139$ \\
\hline $\begin{array}{c}K_{D},(\mathrm{~mL} / \mathrm{ng}) \\
5.834\end{array}$ & $K_{A}(\mathrm{ng} / \mathrm{mL}): 0.444$ & $K_{A}: 0.589$ & $R^{2}: 0.929$ & $K_{D}: 2.070$ \\
\hline \multirow[t]{2}{*}{$R^{2}: 0.806$} & $K_{D}(\mathrm{~mL} / \mathrm{ng}): 2.252$ & $R^{2}: 0.987$ & & $K_{A}: 0.483$ \\
\hline & $R^{2}: 0.876$ & & & $R^{2}: 0.831$ \\
\hline
\end{tabular}

(c)

\begin{tabular}{|c|c|c|c|c|}
\hline $\begin{array}{l}\text { Equilibrium } \\
\text { analysis } \\
\text { (Scathard) }\end{array}$ & $\begin{array}{l}\text { Association } \\
\text { kinetics } \\
\text { analysis }\end{array}$ & Langmuir & Freundlich & $\begin{array}{l}\text { Langmuir- } \\
\text { Freundlich }\end{array}$ \\
\hline$\Delta R_{\max }:$ & $k_{a}(\mathrm{ng} / \mathrm{mL} . \mathrm{s}):$ & $\Delta R_{\max }:$ & $\Delta R_{\max }:$ & \multirow{2}{*}{$\Delta R_{\max }: 0.196$} \\
\hline 18.704 & 0.008 & 4.549 & 18.791 & \\
\hline $\begin{array}{c}K_{A}(\mathrm{ng} / \mathrm{mL}): \\
0.916\end{array}$ & $k_{d}(1 / \mathrm{s}): 0.009$ & $K_{D}: 0.648$ & $1 / n: 1.1851$ & $1 / n: 1.1851$ \\
\hline $\begin{array}{c}K_{D}(\mathrm{~mL} / \mathrm{ng}): \\
1.092\end{array}$ & $\begin{array}{c}K_{A}(\mathrm{ng} / \mathrm{mL}): \\
0.854\end{array}$ & $K_{A}: 1.542$ & $R^{2}: 0.928$ & $K_{D}: 0.766$ \\
\hline \multirow[t]{2}{*}{$R^{2}: 0.833$} & $\begin{array}{c}K_{D}(\mathrm{~mL} / \mathrm{ng}): \\
1.171\end{array}$ & $R^{2}: 0.999$ & & $K_{A}: 0.131$ \\
\hline & $R^{2}: 0.984$ & & & $R^{2}: 0.869$ \\
\hline
\end{tabular}

The $L O D$ values were calculated as $1.6 \times 10^{-4} \mathrm{ng} / \mathrm{mL}$ for vitamin B2, $13.5 \times 10^{-4} \mathrm{ng} / \mathrm{mL}$ for vitamin $\mathrm{B} 9$, and $2.5 \times 10^{-4} \mathrm{ng} / \mathrm{mL}$ for vitamin $\mathrm{B} 12$, respectively. The $L O Q$ values were calculated as $5.2 \times 10^{-4} \mathrm{ng} / \mathrm{mL}$ for vitamin B2, $45 \times 10^{-4} \mathrm{ng} / \mathrm{mL}$ for vitamin $\mathrm{B}$, and $8.2 \times 10^{-4} \mathrm{ng} / \mathrm{mL}$ for vitamin $\mathrm{B} 12$, respectively. A summary of the different detection methods for vitamins B2, B9, and B12 was given in Table 2. This table compares the limit of detection and linear concentration range of the proposed sensor for vitamins B2, B9, and B12 detection with those of vitamins B2, B9, and B12 sensors previously reported in the literature. Molecular imprinted based prepared SPR sensors are rapid, selective, and sensitive devices for vitamin detection. In this study, the molecular imprinting technique is integrated with sensor platforms in order to push the sensitivity and selectivity of these platforms. Vitamins B2, B9, and B12 imprinted SPR sensors have a low limit of detection, high stability, sensitivity, and selectivity compared with other studies in literature.

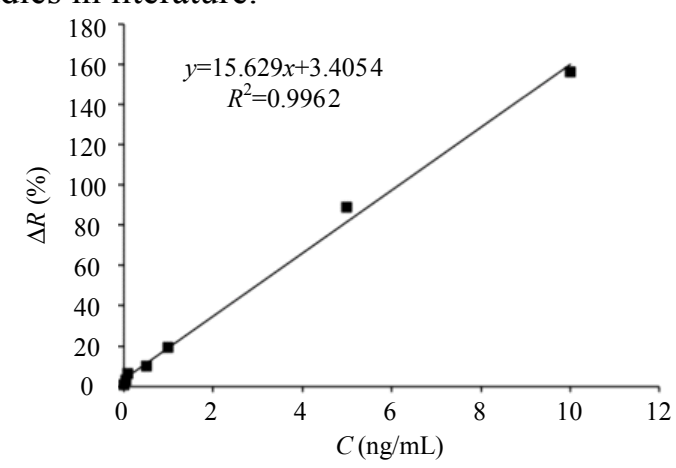

(a)

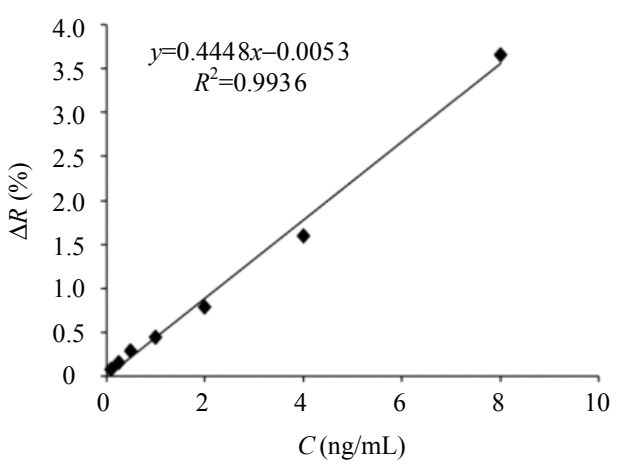

(b)

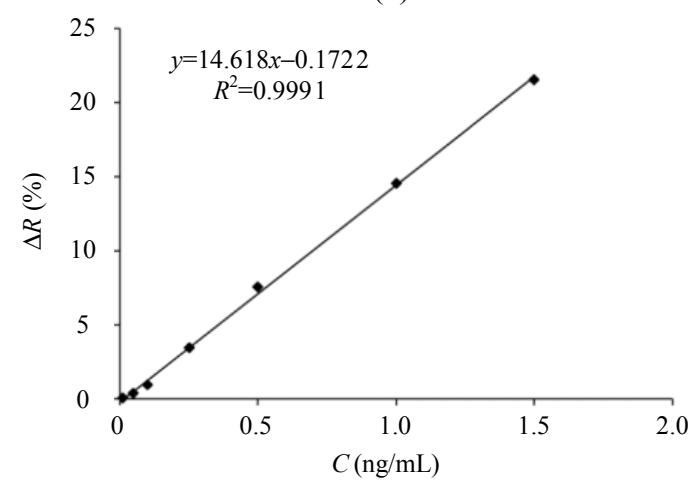

(c)

Fig. 7 Standard calibration curves [(a) vitamin B2 imprinted SPR sensor, (b) vitamin B9 imprinted SPR sensor, and (c) vitamin B12 imprinted SPR sensor]. 
Vitamins in Infact Formula and Milk Samples

Table 2 Comparison of vitamins B2, B9, and B12 detection methods.

\begin{tabular}{|c|c|c|c|}
\hline Detection systems & $\begin{array}{l}\text { Vitamin type and } \\
\text { detection range }\end{array}$ & LOD & Ref. \\
\hline $\begin{array}{c}\text { Quartz crystal } \\
\text { microbalance (QCM) }\end{array}$ & $\begin{array}{l}\text { Vitamin B9 }(0 \mathrm{ng} / \mathrm{mL} \\
-44140 \mathrm{ng} / \mathrm{mL})\end{array}$ & $\begin{array}{c}6797.56 \\
\mathrm{ng} / \mathrm{mL}\end{array}$ & [39] \\
\hline $\begin{array}{c}\text { Dipstick based } \\
\text { immunochemiluminescence } \\
\text { biosensor }\end{array}$ & $\begin{array}{l}\text { Vitamin B12 }(1.0 \mathrm{ng} / \mathrm{mL} \\
-500 \mathrm{ng} / \mathrm{mL})\end{array}$ & $1.0 \mathrm{ng} / \mathrm{mL}$ & {$[40]$} \\
\hline $\begin{array}{c}\text { Quartz crystal } \\
\text { microbalance (QCM) }\end{array}$ & $\begin{array}{l}\text { Vitamin B9 }(0 \mathrm{ng} / \mathrm{mL} \\
\left.-5.0 \times 10^{5} \mathrm{ng} / \mathrm{mL}\right)\end{array}$ & $\begin{array}{r}1.0 \mathrm{ng} / \mathrm{mL}- \\
30000 \mathrm{ng} / \mathrm{mL}\end{array}$ & [41] \\
\hline $\begin{array}{l}\text { Immunodipstick based } \\
\text { gold nanosensor }\end{array}$ & Vitamin B12 -------- & $1.0 \mathrm{ng} / \mathrm{mL}$ & [42] \\
\hline Fluorometric detection & $\begin{array}{l}\text { Vitamin B2 }(125 \mathrm{ng} / \mathrm{mL} \\
\left.-2.0 \times 10^{3} \mathrm{ng} / \mathrm{mL}\right)\end{array}$ & $300 \mathrm{ng} / \mathrm{mL}$ & [43] \\
\hline $\begin{array}{c}\text { Quartz crystal } \\
\text { microbalance (QCM) }\end{array}$ & $\begin{array}{l}\text { Vitamin B9 }(0.6 \mathrm{ng} / \mathrm{mL} \\
-26.0 \mathrm{ng} / \mathrm{mL})\end{array}$ & $0.08 \mathrm{ng} / \mathrm{mL}$ & [44] \\
\hline Electrochemical sensor & $\begin{array}{l}\text { Vitamin B2 }(3.67 \mathrm{ng} / \mathrm{mL} \\
-451.36 \mathrm{ng} / \mathrm{mL})\end{array}$ & $0.897 \mathrm{ng} / \mathrm{mL}$ & {$[45]$} \\
\hline Electrochemical sensor & $\begin{array}{l}\text { VitaminB12(3388ng/mL } \\
-677.68 \mathrm{ng} / \mathrm{mL})\end{array}$ & $1.233 \mathrm{ng} / \mathrm{mL}$ & [46] \\
\hline Voltammetric sensor & $\begin{array}{l}\text { Vitamin B9(35.312ng/mL } \\
-286913 \mathrm{ng} / \mathrm{mL})\end{array}$ & $22.07 \mathrm{ng} / \mathrm{mL}$ & {$[47]$} \\
\hline \multirow{3}{*}{ SPR } & $\begin{array}{l}\text { Vitamin B2 }(0.01 \mathrm{ng} / \mathrm{mL} \\
-10 \mathrm{ng} / \mathrm{mL})\end{array}$ & $\begin{array}{l}\text { Vitamin B2 for } \\
1.6 \times 10^{-4} \mathrm{ng} / \mathrm{mL}\end{array}$ & \multirow{3}{*}{$\begin{array}{l}\text { This } \\
\text { work }\end{array}$} \\
\hline & $\begin{array}{l}\text { Vitamin B9 }(0.1 \mathrm{ng} / \mathrm{mL} \\
-8.0 \mathrm{ng} / \mathrm{mL})\end{array}$ & $\begin{array}{l}\text { Vitamin B9 for } \\
13.5 \times 10^{-4} \mathrm{ng} / \mathrm{mL}\end{array}$ & \\
\hline & $\begin{array}{l}\text { Vitamin B12 }(0.01 \mathrm{ng} / \mathrm{mL} \\
\quad-1.5 \mathrm{ng} / \mathrm{mL})\end{array}$ & $\begin{array}{l}\text { Vitamin B12 for } \\
25 \times 10^{-4} \mathrm{ng} / \mathrm{mL}\end{array}$ & \\
\hline
\end{tabular}

\subsection{Selectivity studies}

The selectivity studies of vitamins B2, B9, and B12 imprinted SPR sensors were examined by using vitamin B1 and vitamin B6 as competitive binding analyses. Selective recognition of vitamin B2 with vitamin B2 imprinted and non-imprinted SPR sensors was examined at $0.01 \mathrm{ng} / \mathrm{mL}$ of each vitamin B1 and vitamin B6 concentrations. Selective recognition of vitamin B9 with vitamin B9 imprinted and non-imprinted SPR sensors was examined at $1.0 \mathrm{ng} / \mathrm{mL}$ of each vitamin $\mathrm{B} 12$ and vitamin B1 concentrations. Selective recognition of vitamin B12 with vitamin B12 imprinted and non-imprinted SPR sensors was examined at $0.1 \mathrm{ng} / \mathrm{mL}$ of each vitamin B1 and vitamin B9 concentrations. In addition, a mixture of vitamin solutions with the same concentrations was evaluated to compare selectivity performance.

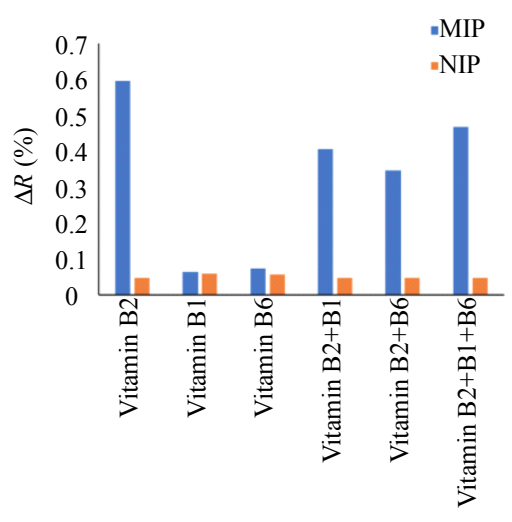

(a)

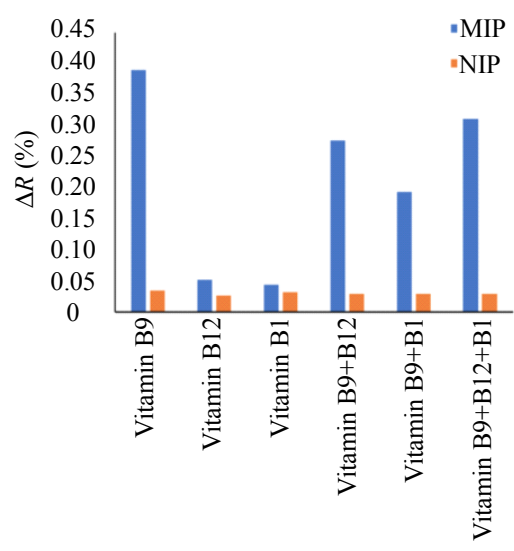

(b)

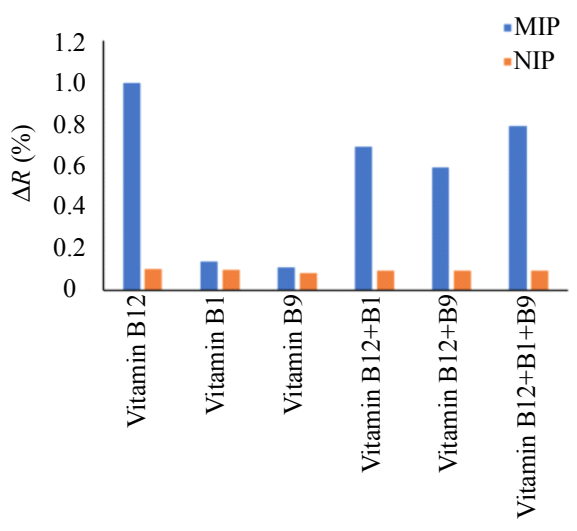

(c)

Fig. 8 Comparison of selectivity of SPR sensor [(a) vitamin B2 imprinted SPR sensor, (b) vitamin B9 imprinted SPR sensor, and (c) vitamin B12 imprinted SPR sensor] $\left(C_{\text {vitamin B2: }}\right.$ : $0.01 \mathrm{ng} / \mathrm{mL}, C_{\text {vitamin Bg}}: 1.0 \mathrm{ng} / \mathrm{mL}$, and $C_{\text {vitaminB12}}: 0.1 \mathrm{ng} / \mathrm{mL}$ in all measurements).

The relative selectivity coefficients $\left(k^{\prime}\right)$ and selectivity coefficients $(k)$ for vitamins $\mathrm{B} 2, \mathrm{~B} 9$, and B12 imprinted SPR sensors were calculated for vitamins B2, B9, and B12 imprinted and non- 
imprinted SPR sensors (Table 3). The binding capacities of vitamins B2, B9, and B12 imprinted SPR chips were higher than those of the non-imprinted SPR sensors in Fig. 8. With respect to these responses, it can be concluded that the vitamins B2, B9, and B12 imprinted SPR sensors recognize vitamins $\mathrm{B} 2, \mathrm{~B} 9$, and $\mathrm{B} 12$ with a high selectivity due to the imprinting process that creates molecular shape and chemical recognition memory.

Table 3 Selectivity and relative selectivity coefficients for competitive molecules [(a) vitamin B2, (b) vitamin B9, and (c) vitamin B12 imprinted SPR sensors].

(a)

\begin{tabular}{cccccc}
\hline \multicolumn{3}{c}{ MIP } & \multicolumn{3}{c}{ NIP } \\
\hline Molecules & $\Delta R(\%)$ & $k$ & $\Delta R(\%)$ & $k$ & $k$ \\
Vitamin B2 & 0.597 & - & 0.046 & - & - \\
Vitamin B1 & 0.064 & 9.33 & 0.059 & 0.77 & 12.12 \\
Vitamin B6 & 0.074 & 8.07 & 0.057 & 0.81 & 9.96 \\
\hline
\end{tabular}

(b)

\begin{tabular}{cccccc}
\hline \multicolumn{3}{c}{ MIP } & \multicolumn{3}{c}{ NIP } \\
\hline Molecules & $\Delta R(\%)$ & $k$ & $\Delta R(\%)$ & $k$ & $k$ \\
Vitamin B9 & 0.434 & - & 0.038 & - & - \\
Vitamin B12 & 0.057 & 7.61 & 0.030 & 1.27 & 5.99 \\
Vitamin B1 & 0.049 & 8.86 & 0.035 & 1.09 & 8.13 \\
\hline
\end{tabular}

(c)

\begin{tabular}{cccccc}
\hline \multicolumn{3}{c}{ MIP } & \multicolumn{3}{c}{ NIP } \\
\hline Molecules & $\Delta R(\%)$ & $k$ & $\Delta R(\%)$ & $k$ & $k$ \\
Vitamin B12 & 0.996 & - & 0.104 & - & - \\
Vitamin B1 & 0.142 & 7.01 & 0.100 & 1.04 & 6.74 \\
Vitamin B9 & 0.113 & 8.81 & 0.086 & 1.21 & 7.28 \\
\hline
\end{tabular}

\subsection{Detection of vitamins B2, B9, and B12 from food samples}

Vitamins B2, B9, and B12 imprinted SPR sensors were applied for the real-time detection of vitamins B2, B9, and B12 from the infant formula and milk samples. Vitamins B2, B9, and B12 ingredients in spiked infact formula and milk samples were determined by using both the prepared SPR sensor and LC-MS/MS. Thermo UHLPC device is connected to TSQ Quantum Access Max MS/MS device with Thermo Scientific TSQ Quantum Access Triple Quadrupole Device (Thermo, San Jose, CA, USA). C18 reverse phase column $(2.1 \times 50 \mathrm{~mm}, 1.7 \mu \mathrm{m})$ was used to determine the amount of vitamins B2, B9, and B12 in food extracts obtained from infant formula and milk samples. As the mobile phase methanol:water $(1: 3, \mathrm{v} / \mathrm{v})$ and $20 \mathrm{mM}$ ammonium formate, vitamins B2, B9, and B12 analyses were performed at $100 \mu \mathrm{L} / \mathrm{min}$ flow rate [48]. Vitamins B2, B9, and B12 ingredients in spiked infact formula and milk samples $(1.0 \mathrm{ng} / \mathrm{mL}$ vitamin concentration) were injected into the device at $20 \mu \mathrm{L}$. The recovery (\%) was calculated to determine the accuracy and reliability of the SPR sensor and LC-MS/MS (Table 4). It was observed that the obtained LC-MS/MS results were consistent with the results of sensors. The results showed that vitamins B2, B9, and B12 imprinted SPR sensors provide an accurate, sensitive, and quantitative assay for the measurement of vitamins B2, B9, and B12 concentrations.

Table 4 Recoveries of vitamins B2, B9, and B12 in food samples $(n: 3)$.

\begin{tabular}{|c|c|c|c|c|c|}
\hline \multicolumn{6}{|c|}{ Vitamin B2 } \\
\hline \multirow{2}{*}{$\begin{array}{c}\text { Food } \\
\text { samples }\end{array}$} & \multirow{2}{*}{$\begin{array}{c}\text { Added } \\
\text { amount } \\
(\mathrm{ng} / \mathrm{mL})\end{array}$} & \multicolumn{2}{|c|}{$\begin{array}{l}\text { Founded amount } \\
\qquad(\mathrm{ng} / \mathrm{mL})\end{array}$} & \multicolumn{2}{|c|}{$\begin{array}{l}\text { Recovery } \\
(\%)\end{array}$} \\
\hline & & SPR & LC-MS/MS & SPR & LC-MS/MS \\
\hline Milk & 1.0 & $1.10 \pm 0.03$ & $0.98 \pm 0.01$ & $110 \pm 1.1$ & $98 \pm 0.7$ \\
\hline Infant formula & 1.0 & $0.99 \pm 0.04$ & $0.99 \pm 0.03$ & $99 \pm 0.8$ & $99 \pm 0.5$ \\
\hline \multicolumn{6}{|c|}{ Vitamin B9 } \\
\hline \multirow{2}{*}{$\begin{array}{c}\text { Food } \\
\text { samples }\end{array}$} & \multirow{2}{*}{$\begin{array}{l}\text { Added } \\
\text { amount } \\
(\mathrm{ng} / \mathrm{mL})\end{array}$} & \multicolumn{2}{|c|}{$\begin{array}{l}\text { Founded amount } \\
(\mathrm{ng} / \mathrm{mL})\end{array}$} & \multicolumn{2}{|c|}{$\begin{array}{c}\text { Recovery } \\
(\%)\end{array}$} \\
\hline & & SPR & LC-MS/MS & SPR & LC-MS/MS \\
\hline Milk & 1.0 & $0.99 \pm 0.02$ & $0.97 \pm 0.04$ & $99 \pm 0.4$ & $97 \pm 0.8$ \\
\hline Infant formula & 1.0 & $0.97 \pm 0.03$ & $0.96 \pm 0.01$ & $97 \pm 0.6$ & $96 \pm 0.6$ \\
\hline \multicolumn{6}{|c|}{ Vitamin B12 } \\
\hline \multirow{2}{*}{$\begin{array}{c}\text { Food } \\
\text { samples }\end{array}$} & \multirow{2}{*}{$\begin{array}{l}\text { Added } \\
\text { amount } \\
(\mathrm{ng} / \mathrm{mL})\end{array}$} & \multicolumn{2}{|c|}{$\begin{array}{l}\text { Founded amount } \\
\qquad(\mathrm{ng} / \mathrm{mL})\end{array}$} & \multicolumn{2}{|c|}{$\begin{array}{c}\text { Recovery } \\
(\%)\end{array}$} \\
\hline & & SPR & LC-MS/MS & SPR & LC-MS/MS \\
\hline Milk & 1.0 & $1.00 \pm 0.05$ & $0.96 \pm 0.01$ & $100 \pm 0.8$ & $96 \pm 0.4$ \\
\hline Infant formula & 1.0 & $0.98 \pm 0.03$ & $0.97 \pm 0.04$ & $98 \pm 0.6$ & $97 \pm 0.6$ \\
\hline
\end{tabular}

\subsection{Reproducibility and stability}

The reproducibility studies were repeated for four times by using vitamins B2, B9, and B12 aqueous solutions in Fig. 9. As seen from Fig. 9, 
vitamins B2, B9, and B12 imprinted SRP sensors have displayed reproducible resonance frequency change $[\Delta R(\%)]$ during the four cycles. Vitamins B2, B9, and B12 imprinted SPR sensors showed that there was no any decrease in binding capacity during the four cycles. It showed that vitamins B2, B9, and B12 imprinted SPR sensors awere stable under long-term storage conditions. In addition,

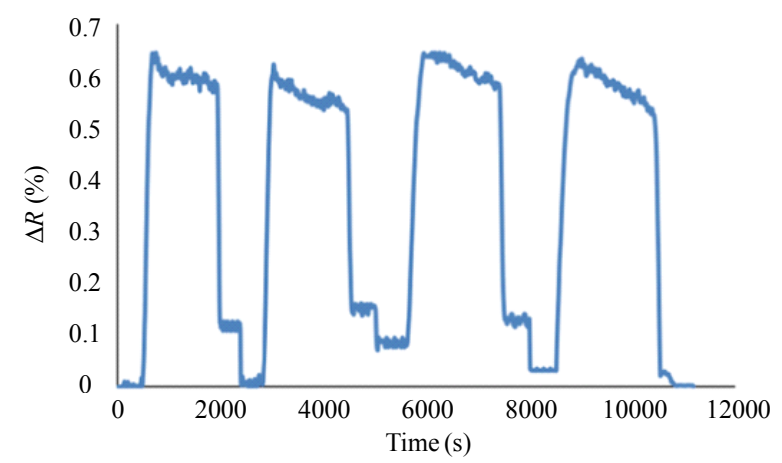

(a)

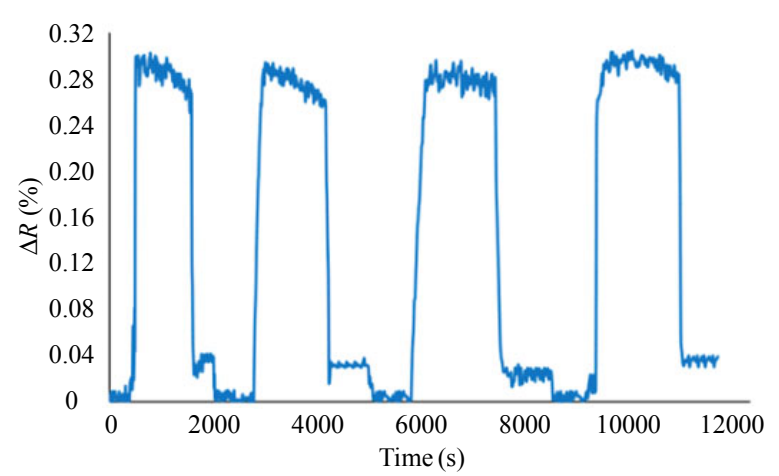

(c)

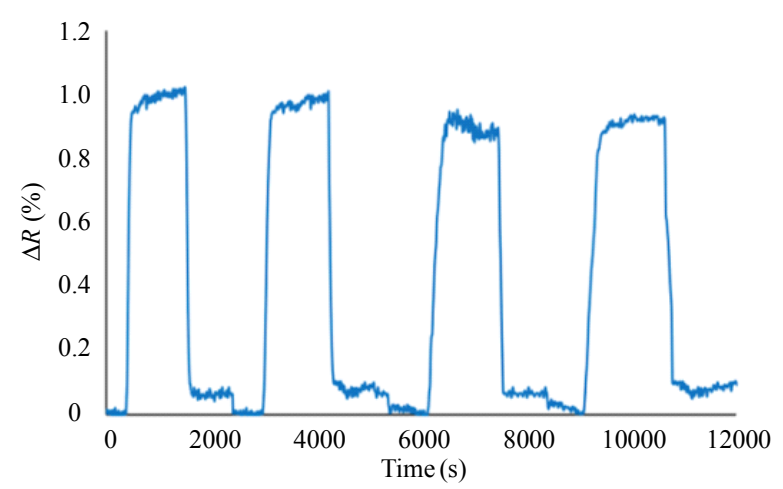

(e) vitamins B2, B9, and B12 imprinted SPR sensors were tested at different time (1 month, 3 months, 9 months, and 27 months) to show storage stability. After 3 months of storage stability of the SPR sensors, $91.54 \%$ for vitamin B2, $90.03 \%$ for vitamin B9, and $91.43 \%$ for vitamin B12 of the initial activity of the SPR sensors remained.

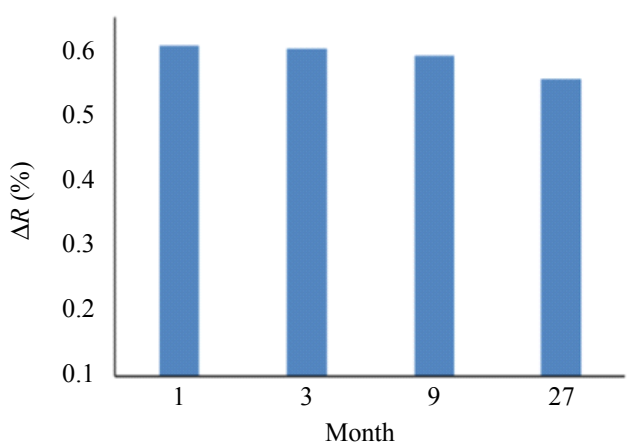

(b)

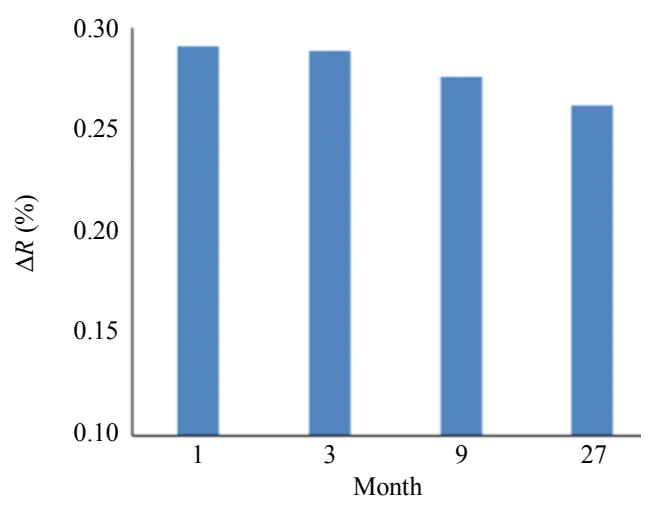

(d)

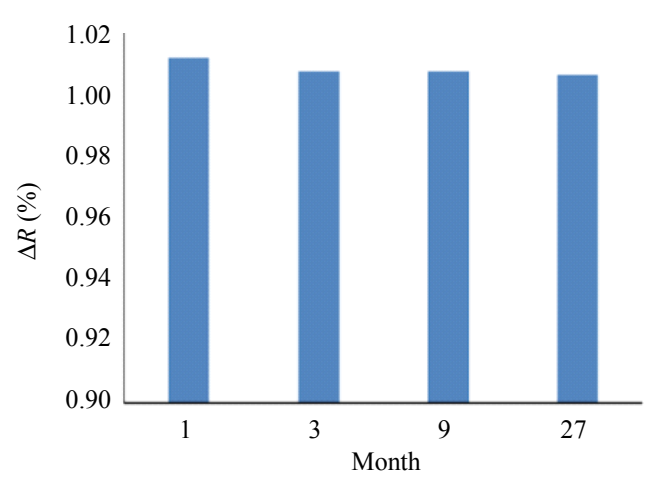

(f)

Fig. 9 Reproducibility [(a), (c), and (e)] and storage stability [(b), (d), and (f)] of vitamin B2, B9,and B12 imprinted SPR sensors [(a) and (b): vitamin B2 imprinted SPR sensor; (c) and (d): vitamin B9 imprinted SPR sensor; (e) and (f): vitamin B12 imprinted SPR sensor] ( $C_{\text {vitamin B2}}: 0.01 \mathrm{ng} / \mathrm{mL}, C_{\text {vitamin B9}}: 0.5 \mathrm{ng} / \mathrm{mL}$, and $C_{\text {vitamin B12}}: 0.1 \mathrm{ng} / \mathrm{mL}$ in all measurements). 


\section{Conclusions}

The control of quality and freshness of foods is very important in the studies of food and biotechnology fields. The chemical and microbiological analyses (such as color, aroma, vitamins, and amino acids) are carried out for quality and safety purposes in food industry. In recent years, certain standards, laws, and monitoring procedures have been established for food safety and component analysis, and food analysis. Factors such as temperature, $\mathrm{pH}$, light, and oxygen cause the loss of vitamins in foods. The amount of vitamins in foods should be determined in foods. In this study, we prepared vitamins B2, B9, and B12 imprinted SPR sensors for the selective and real-time detection of vitamins B2, B9, and B12 from aqueous solution and infant formula and milk samples. The prepared SPR sensors successfully detected very low detection limits of vitamins B2, B9, and B12 without any significant changes in its specificity and selectivity after periods as long as several months. The $L O D$ values were calculated as $0.00016 \mathrm{ng} / \mathrm{mL}$ for vitamin B2, $0.00135 \mathrm{ng} / \mathrm{mL}$ for vitamin B9, and $0.00025 \mathrm{ng} / \mathrm{mL}$ for vitamin B12, respectively. After 3 months of storage stability of the SPR sensors, $91.54 \%$ for vitamin B2, $90.03 \%$ for vitamin B9, and $91.43 \%$ for vitamin B12 of the initial activity of the SPR sensors remained. Vitamins B2, B9, and B12 imprinted SPR sensors showed high stability, sensitivity, and selectivity and desired efficiency for the detection of vitamins B2, B9, and B12 in infant formula and milk samples. Experimental results show that vitamins B2, B9, and B12 imprinted SPR sensors combined with the molecular imprinting process provide a promising tool for selective detection of vitamin in different food samples in the future.

\section{Acknowledgment}

This study is supported by a grant from Hacettepe University Scientific Research Projects
Coordination Unit (Grant No. FBA-2015-8761).

Open Access This article is distributed under the terms of the Creative Commons Attribution 4.0 International License (http://creativecommons.org/licenses/by/4.0/), which permits unrestricted use, distribution, and reproduction in any medium, provided you give appropriate credit to the original author(s) and the source, provide a link to the Creative Commons license, and indicate if changes were made.

\section{References}

[1] M. M. Phillips, "Liquid chromatography with isotope-dilution mass spectrometry for determination of water-soluble vitamins in foods," Analytical and Bioanalytical Chemistry, 2015, 407(11): 2965-2974.

[2] A. C. Ortega, D. C. Silva, J. V. Visentainer, N. E. Souza, V. C. Almeida, and C. C. Oliveira, "Determination of vitamins A and E exploiting cloud point extraction and micellar liquid chromatography," Analytical Letters, 2011, 44(5): 778-786.

[3] L. Mirmoghtadaie, A. A. Ensafi, M. Kadivar, M. Shahedi, and M. R. Ganjal, "Highly selective, sensitive and fast determination of folic acid in food samples using new electrodeposited gold nanoparticles by differential pulse voltammetry," International Journal of Electrochemical Science, 2013, 8: 3755-3767.

[4] B. J. Petteys and E. L. Frank, "Rapid determination of vitamin $\mathrm{B}_{2}$ (riboflavin) in plasma by HPLC," Clinica Chimica Acta, 2011, 412(1-2): 38-43.

[5] A. Schmidt, M. G. Schreiner, and H. K. Mayer, "Rapid determination of the various native forms of vitamin $\mathrm{B}_{6}$ and $\mathrm{B}_{2}$ in cow's milk using ultra-high performance liquid chromatography," Journal of Chromatography A, 2017, 1500: 89-95.

[6] E. Campos-Giménez, S. Bénet, Y. Oguey, F. Martin, and K. Redeuil, "The contribution of minor folates to the total vitamin B9 content of infant formula and clinical nutrition products," Food Chemistry, 2018, 249: 91-97.

[7] A. Babakhanian, S. Kaki, M. Ahmadi, H. Ehzari, and A. Pashabadi, "Development of $\alpha$-polyoxometalatepolypyrrole-Au nanoparticles modified sensor applied for detection of folic acid," Biosensors and Bioelectronics, 2014, 60: 185-190.

[8] M. Nakos, I. Pepelanova, S. Beutel, U. Krings, R. G. Berger, and T. Scheper, "Isolation and analysis of vitamin $\mathrm{B}_{12}$ from plant samples," Food Chemistry, 2017, 216: 301-308.

[9] Y. Yamini, E. Tahmasebi, and L. Ranjbar, "Magnetic nanoparticle-based solid-phase extraction of vitamin 
$\mathrm{B}_{12}$ from pharmaceutical formulations," Biological Trace Element Research, 2012, 147(1): 378-385.

[10] X. He, M. Meng, and R. Xi, "Indirect competitive immunoassay for detection of vitamin $\mathrm{B}_{2}$ in foods and pharmaceuticals," Journal of Agricultural Food Chemistry, 2013, 61(29): 7048-7054.

[11] D. Hampel, S. Shahab-Ferdows, J. M. Domek, T. Siddiqua, R. Raqib, and L. H. Allen, "Competitive chemiluminescent enzyme immunoassay for vitamin B12 analysis in human milk," Food Chemistry, 2014, 153: 60-65.

[12] X. Luo, B. Chen, L. Ding, F. Tang, and S. Yao, "HPLC-ESI-MS analysis of vitamin $\mathrm{B}_{12}$ in food products and in multivitamins-multimineral tablets," Analytica Chimica Acta, 2006, 562(2): 185-189.

[13] R. J. Kelly, T. M. Gruner, J. M. Furlong, and A. R. Sykes, "Analysis of corrinoids in ovine tissues," Biomedical Chromatography, 2006, 20(8): 806-814.

[14] F. Samari, B. Hemmateenejad, Z. Rezaei, and M. Shamsipur, "A novel approach for rapid determination of vitamin B12 in pharmaceutical preparations using BSA-modified gold nanoclusters," Analytical Methods, 2012, 4(12): 4155-4160.

[15] N. Pourreza, R. Mirzajani, and J. Burromandpiroze, "Fluorescence detection of vitamin B12 in human plasma and urine samples using silver nanoparticles embedded into chitosan in micellar media," Analytical Methods, 2017, 9(27): 4052-4059.

[16] Y. Yanase, T. Hiragun, T. Yanase, T. Kawaguchi, K. Ishii, and M. Hide, "Application of SPR imaging sensor for detection of individual living cell reactions and clinical diagnosis of type I allergy," Allergology International, 2013, 62(2): 163-169.

[17] G. Ertürk, H. Özen, M. A. Tümer, B. Mattiasson, and A. Denizli, "Microcontact imprinting based surface plasmon resonance (SPR) biosensor for real-time and ultrasensitive detection of prostate specific antigen (PSA) from clinical samples," Sensors and Actuators B: Chemical, 2016, 224: 823-832.

[18] H. E. Indyk and D. C. Woollard, "Single laboratory validation of an optical biosensor method for the determination of folate in foods," Journal of Food Composition and Analysis, 2013, 29(2): 87-93.

[19] S. Hüseynli, D. Çimen, N. Bereli, and A. Denizli, "Molecular imprinted based quartz crystal microbalance nanosensors for mercury detection," Global Challenges, 2019, 3(3): 1-7.

[20] F. Kartal, D. Çimen, N. Bereli, and A. Denizli, "Molecularly imprinted polymer based quartz crystal microbalance sensor for the clinical detection of insulin," Materials Science \& Engineering: C, 2019, 97: 730-737.

[21] K. Haupt and K. Mosbach, "Molecularly imprinted polymers and their use in biomimetic sensors," Chemical Reviews, 2000, 100(7): 2495-2504.

[22] N. Bereli, M. Andaç, G. Baydemir, R. Say, I. G.
Galaev, and A. Denizli, "Protein recognition via ion-coordinated molecularly imprinted supermacroporous cryogels," Journal of Chromatography A, 2008, 1190(1-2): 18-26.

[23] Y. Saylan, S. Akgönüllü, D. Çimen, A. Derazshamshir, N. Bereli, F. Yılmaz and A. Denizli, "Development of surface plasmon resonance sensors based on molecularly imprinted nanofilms for sensitive and selective detection of pesticides," Sensor and Actuators B: Chemical, 2017, 241: 446-454.

[24] X. Ding and P. A. Heiden, "Recent developments in molecularly imprinted nanoparticles by surface imprinting techniques," Macromolecular Materials and Engineering, 2014, 299(3): 268-282.

[25] I. Caelen, A. Kalman, and L. Wahlstro, "Biosensor-based determination of riboflavin in milk samples," Analytical Chemistry, 2004, 76(1): 137-143.

[26] M. Jung, B. Kim, D. W. Boo, and H. Y. So, "Development of isotope dilution-liquid chromatography/tandem mass spectrometry as a candidate reference method for the determination of folic acid in infant milk formula," Bulletin of the Korean Chemical Society, 2007, 28(5): 745-750.

[27] C. Isabelle, K. Andras, and W. Lennart, "Biosensor-based determination of riboflavin in milk samples," Analytical Chemistry, 2004, 76(1): 137-143.

[28] P. Bairi, P. Chakraborty, S. Mondal, B. Roy, and A. K. Nandi, "A thixotropic supramolecular hydrogel of adenine and riboflavin-5'-phosphate sodium salt showing enhanced fluorescence properties," Soft Matter, 2014, 10(28): 5114-5120.

[29] M. Ye, D. Zhang, L. Han, J. Tejada, and C. Ortiz, "Synthesis, preparation, and conformation of stimulus-responsive end-grafted poly (methacrylic acid-g-ethylene glycol) layers," Soft Matter, 2006, 2(3): 243-256.

[30] E. Assadpour, S. M. Jafari, and Y. Maghsoudlou, "Evaluation of folic acid release from spray dried powder particles of pectin-whey protein nano-capsules," International Journal of Biological Macromolecules, 2017, 95: 238-247.

[31] Y. H. Wu and B. D. Freeman, "Structure, water sorption, and transport properties of crosslinked N-vinyl-2-pyrrolidone/N,N'-methylenebisacrylamide films," Journal of Membrane Science, 2009, 344(1-2): 182-189.

[32] M. Gharagozlou and S. Naghibi, "Preparation of vitamin $\mathrm{B}_{12}-\mathrm{TiO}_{2}$ nanohybrid studied by TEM, FTIR and optical analysis techniques," Materials Science in Semiconductor Processing, 2015, 35: 166-173.

[33] I. Göktürk, I. Perçin, and A. Denizli, "Catalase purification from rat liver with iron-chelated poly(hydroxyethyl methacrylate- $N$-methacryloyl(L)-glutamic acid) cryogel discs," Preparative 
Biochemistry and Biotechnology, 2016, 46(6): 602-609.

[34] M. Lasáková and P. Jandera, "Molecularly imprinted polymers and their application in solid phase extraction," Journal of Separation Science, 2009, 32(5-6): 788-812.

[35] S. K. Papageorgiou, F. K. Katsaros, E. P. Kouvelos, and N. K. Kanellopoulos, "Prediction of binary adsorption isotherms of $\mathrm{Cu}^{2+}, \mathrm{Cd}^{2+}$ and $\mathrm{Pb}^{2+}$ on calcium alginate beads from single adsorption data," Journal of Hazardous Materials, 2009, 162(2-3): 1347-1354.

[36] X. Zhu, Y. Guo, H. Ren, C. Gao, and Y. Zhou, "Enhancing the $\mathrm{NO}_{2}$ gas sensing properties of $\mathrm{rGO} / \mathrm{SnO}_{2}$ nanocomposite films by using microporous substrates," Sensor and Actuators B: Chemical, 2017, 248: 560-570.

[37] Y. Zhou, G. Liu, X. Zhu, and Y. Guo, "Ultrasensitive $\mathrm{NO}_{2}$ gas sensing based on $\mathrm{rGO} / \mathrm{MoS}_{2}$ nanocomposite film at low temperature," Sensor and Actuators B: Chemical, 2017, 251: 280-290.

[38] Y. Zhou, C. Gao, and Y. C. Guo, "UV assisted ultrasensitive trace $\mathrm{NO}_{2}$ gas sensing based on few-layer $\mathrm{MoS}_{2}$ nanosheet-ZnO nanowire heterojunctions at room temperature," Journal of Materials Chemistry A, 2018, 6: 10286-10296.

[39] D. C. Apodaca, R. B. Pernites, R. R. Ponnapati, F. R. D. Mundo, and R. C. Advincula, "Electropolymerized molecularly imprinted polymer films of a bis-terthiophene dendron: folic acid quartz crystal microbalance sensing," ACS Applied Materials Interfaces, 2011, 3(2): 191-203.

[40] L. S. Selvakumar and M. S. Thakur, "Dipstick based immunochemiluminescence biosensor for the analysis of vitamin $\mathrm{B}_{12}$ in energy drinks: a novel approach," Analytica Chimica Acta, 2012, 722: 107-113.

[41] M. Hussain, N. Iqbal, and P. A. Lieberzei, "Acidic and basic polymers for molecularly imprinted folic acid sensors-QCM studies with thin films and nanoparticles," Sensors and Actuators: B, 2013, 176: 1090-1095.

[42] L. S. Selvakumar, K. V. Ragavan, K. S. Abhijith, and M. S. Thakur, "Immunodipstick based gold nanosensor for vitamin $\mathrm{B}_{12}$ in fruit and energy drinks," Analytical Methods, 2013, 5(7): 1806-1810.

[43] M. V. Osorio, S. S. Marques, H. M. Oliveira, L. Barreiros, and M. A. Segundo, "Fluorometric method based on molecular recognition solid-phase extraction for determination of riboflavin in milk and infant formula," Journal of Food Composition and Analysis, 2016, 45: 141-146.

[44] R. Madhuri, M. P. Tiwari, D. Kumar, A. Mukharji, and B. B. Prasad, "Biomimetic piezoelectric quartz sensor for folic acid based on a molecular imprinting technology," Advanced Materials Letters, 2011, 2(4): 264-267.

[45] P. Xu, C. Qiao, S. Yang, L. Liu, M. Wang, and J. Zhang, "Fast determination of vitamin $\mathrm{B}_{2}$ based on molecularly imprinted electrochemical sensor," Engineering, 2012, 5: 129-134.

[46] M. H. Parvin, E. Azizi, J. Arjomandi, and J. Y. Lee, "Highly sensitive and selective electrochemical sensor for detection of vitamin B12 using an Au/PPy/FMNPs@TD-modified electrode," Sensors and Actuators: B, 2018, 261: 335-344.

[47] F. Khaleghi, A. E. Irai, R. Sadeghi, V. K. Gupta, and Y. Wen, "A fast strategy for determination of vitamin $\mathrm{B}_{9}$ in food and pharmaceutical samples using an ionic liquid-modified nanostructure voltammetric sensor," Sensors, 2016, 16(6): 747.

[48] N. A. Cellar, S. C. Mcclure, L. M. Salvati, and T. M. Reddy, "A new sample preparation and separation combination for precise, accurate, rapid, and simultaneous determination of vitamins $B_{1}, B_{2}, B_{3}$, $\mathrm{B}_{5}, \mathrm{~B}_{6}, \mathrm{~B}_{7}$, and $\mathrm{B}_{9}$ in infant formula and related nutritionals by LC-MS/MS," Analytica Chimica Acta, 2016, 934: 180-185. 